\title{
Development of Covalent Ligands for G Protein-Coupled Receptors: A Case for the Human Adenosine $A_{3}$ Receptor
}

Xue Yang, Jacobus P. D. van Veldhoven, Jelle Offringa, Boaz J. Kuiper, Eelke B. Lenselink, Laura H. Heitman, Daan van der Es, ${ }^{\circledR}$ and Adriaan P. IJzerman*(1)

Division of Drug Discovery and Safety, Leiden Academic Centre for Drug Research, Leiden University, Einsteinweg 55, 2333 CC Leiden, The Netherlands

\section{Supporting Information}

ABSTRACT: The development of covalent ligands for G proteincoupled receptors (GPCRs) is not a trivial process. Here, we report a streamlined workflow thereto from synthesis to validation, exemplified by the discovery of a covalent antagonist for the human adenosine $\mathrm{A}_{3}$ receptor $\left(\mathrm{hA}_{3} \mathrm{AR}\right)$. Based on the $1 \mathrm{H}, 3 \mathrm{H}$ pyrido[2,1-f]purine-2,4-dione scaffold, a series of ligands bearing a fluorosulfonyl warhead and a varying linker was synthesized. This series was subjected to an affinity screen, revealing compound $\mathbf{1 7 b}$ as the most potent antagonist. In addition, a nonreactive methylsulfonyl derivative $\mathbf{1 9}$ was developed as a reversible control compound. A series of assays, comprising time-dependent affinity determination, washout experiments, and $\left[{ }^{35} \mathrm{~S}\right] \mathrm{GTP} \gamma \mathrm{S}$ binding assays, then validated $\mathbf{1 7} \mathbf{b}$ as the covalent antagonist. A combined in

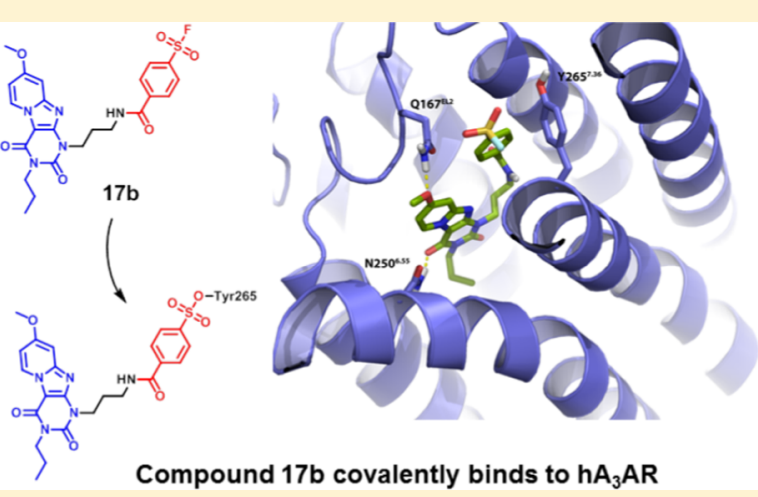
silico $\mathrm{hA}_{3} \mathrm{AR}$-homology model and site-directed mutagenesis study was performed to demonstrate that amino acid residue Y265 $5^{7.36}$ was the unique anchor point of the covalent interaction. This workflow might be applied to other GPCRs to guide the discovery of covalent ligands.

\section{INTRODUCTION}

The adenosine $A_{3}$ receptor $\left(A_{3} A R\right)$ is one of four $G$ proteincoupled receptor subtypes stimulated by adenosine. ${ }^{1}$ Different from the other subtypes $\left(A_{1}, A_{2 A}\right.$ and $\left.A_{2 B}\right) A_{3} A R$ was identified by molecular biology studies prior to its pharmacological characterization. ${ }^{2}$ The initial studies indicated its important role in both physiological and pathophysiological conditions, such as cell proliferation, cell differentiation, neuroprotection, cardioprotection, and apoptosis. ${ }^{3}$ Nevertheless, the medical relevance of the human adenosine $A_{3}$ receptor $\left(h \mathrm{~A}_{3} \mathrm{AR}\right)$ is enigmatic due to its dichotomy in different therapeutic applications. ${ }^{3}$ In this regard, there is a continuing interest in the development of selective ligands of the $\mathrm{hA}_{3} \mathrm{AR}$ to investigate its pharmacological effects. For instance, selective $A_{3} A R$ antagonists have been applied for the treatment of glaucoma ${ }^{4}$ and respiratory tract inflammation such as asthma. In particular, a tricyclic xanthine derivative, 1benzyl-8-methoxy-3-propyl- $1 H, 3 H$-pyrido[2,1-f]purine-2,4dione (compound 1, Figure 1A), has been reported to exert high affinity for the $\mathrm{hA}_{3} \mathrm{AR}^{6-8}$

Initial efforts to study the structural biology of GPCRs suffered from numerous limitations, such as low expression, dynamic conformational states, and inherent instability. Covalent ligands, i.e., compounds that irreversibly bind to the receptor and possess a reactive moiety to target specific amino acid residues, helped to solve some of these obstacles. This is also the case for adenosine receptors. For example, the
A
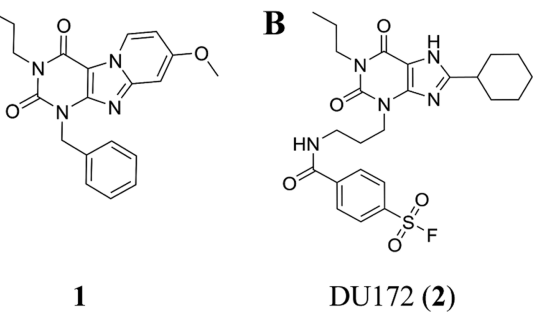

DU172 (2)

Figure 1. (A) Reference antagonist (1) for $h A_{3} A R$. (B) DU172 (2), a covalent antagonist for $\mathrm{hA}_{1} \mathrm{AR}$.

structure of the human adenosine $A_{1}$ receptor, having the highest similarity to the $\mathrm{hA}_{3} \mathrm{AR}$ among all adenosine receptor subtypes ( $61 \%$ of sequence homology), ${ }^{10}$ has been elucidated by X-ray crystallography with a covalent antagonist DU172 (2) (Figure 1B). ${ }^{11}$ However, the application of covalent ligands in $\mathrm{hA} \mathrm{A}_{3} \mathrm{AR}$ studies has been limited to the characterization of the receptor type, ${ }^{12-14}$ far from providing a comprehensive study of receptor structure elucidation, pharmacological characteristics, and ligand-receptor binding description.

To this end, we devoted our efforts to the discovery of a well-defined covalent antagonist based on xanthine analogue 1 mentioned above. Inspired by the resemblance in the chemical

Received: December 27, 2018

Published: March 14, 2019 
Scheme 1. Synthetic Route toward Scaffold $7^{a}$<smiles>CCCn1c(=O)c2c(nc3cc(OC)ccn32)n(Cc2ccccc2)c1=O</smiles>

${ }^{a}$ Reagents and conditions: (a) (i) $\mathrm{Ac}_{2} \mathrm{O}, 80^{\circ} \mathrm{C}, 2 \mathrm{~h}$; (ii) $\mathrm{Et}_{2} \mathrm{O}$, room temperature (rt), $1 \mathrm{~h}$; (iii) $3 \mathrm{M} \mathrm{NaOH}, 85^{\circ} \mathrm{C}, 1 \mathrm{~h}$; (iv) $\mathrm{HCl}(37 \%), 25 \%$; (b) (i) NBS, MeCN, $80{ }^{\circ} \mathrm{C}$; (ii) 4-methoxypyridine, $80{ }^{\circ} \mathrm{C}$, 64\%; (c) 1-bromopropane, 1,8-diazabicyclo[5.4.0] undec-7-ene (DBU), MeCN, $70{ }^{\circ} \mathrm{C}$, $73 \%$; (d) $\mathrm{Pd}(\mathrm{OH})_{2} / \mathrm{C}, \mathrm{HCOONH}_{4}, \mathrm{EtOH}$, reflux, $40 \%$.

Scheme 2. Synthetic Route toward the Bromoalkyl Fluorosulfonylbenzoates $13 a-c$ and $14 a-c^{a}$
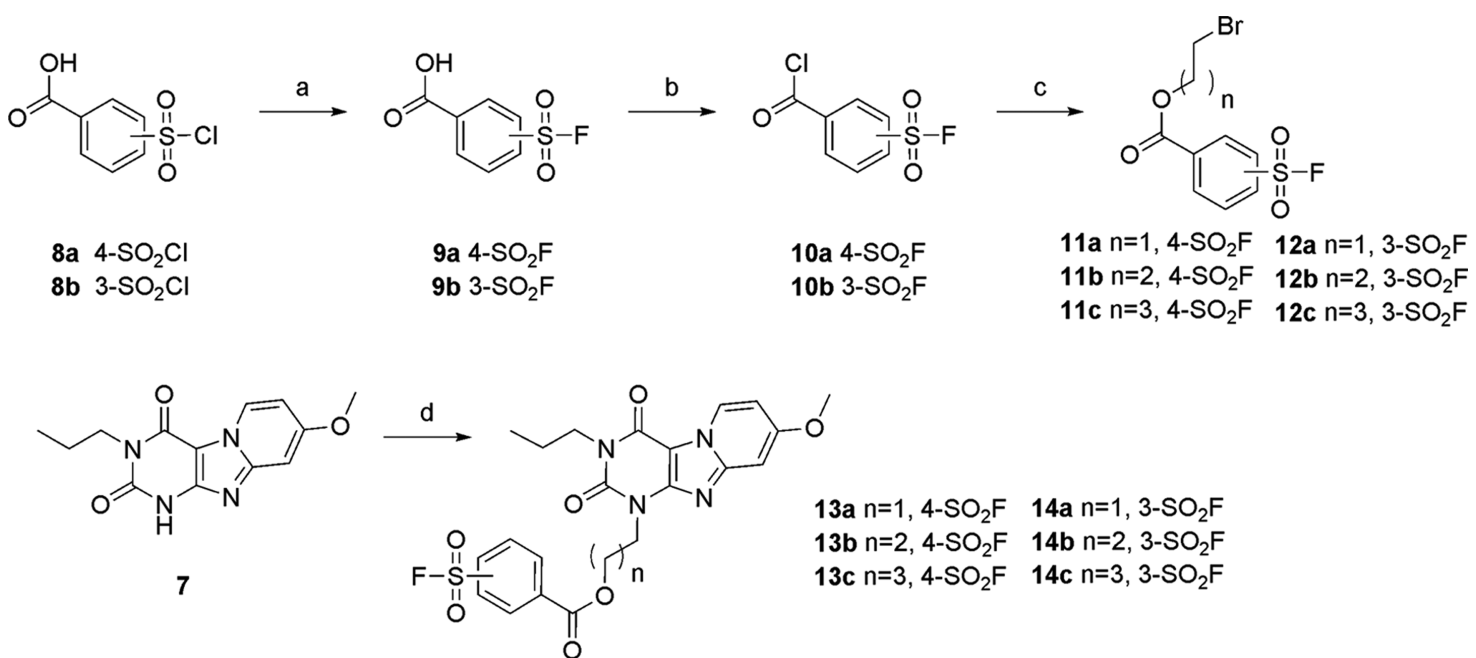

${ }^{a}$ Reagents and conditions: (a) $2 \mathrm{M} \mathrm{KHF}_{2}$ solution, dioxane, rt, $1 \mathrm{~h}, 87-90 \%$; (b) $\mathrm{SOCl}_{2}$ reflux; (c) corresponding bromoalkylalcohol, anhydrous dioxane, $100{ }^{\circ} \mathrm{C}, 18 \mathrm{~h}, 55-83 \%$, (d) $11 \mathrm{a}-\mathrm{c}$ or $12 \mathrm{a}-\mathrm{c}, \mathrm{K}_{2} \mathrm{CO}_{3}$, anhydrous DMF, $50{ }^{\circ} \mathrm{C}, 5-57 \%$.

structure between the potent $\mathrm{hA}_{3} \mathrm{AR}$ antagonist 1 and irreversible adenosine $A_{1}$ receptor antagonist 2, we incorporated the reactive moiety, a fluorosulfonyl benzoyl group, connected to a spacer, at the $\mathrm{N}^{1}$ position of the scaffold. Using a structured approach to bring the reactive fluorosulfonyl group in close proximity to a nucleophilic amino acid residue, we diversified the type of linker, linker length, and position of the fluorosulfonyl substituent on the phenyl group, resulting in a series of analogues with a wide range of affinities. Our efforts led to the discovery of a best-in-class antagonist, $\mathbf{1 7} \mathbf{b}$, which is bound to the $\mathrm{hA}_{3} \mathrm{AR}$ with an apparent affinity in the nanomolar range. To retain the chemical structure similarity, we replaced the warhead with a methylsulfonyl moiety to obtain a nonreactive derivative $\mathbf{1 9}$ as a reversible control compound. $17 \mathbf{b}$ was then validated to covalently bind and inactivate the $\mathrm{hA}_{3} \mathrm{AR}$ in an insurmountable manner. Molecular modeling suggested the fluorosulfonyl functionality of $\mathbf{1 7 b}$ in close proximity to $\mathrm{Y} 265^{7.36}$, which was identified as the unique anchor point of the covalent interaction in a subsequent mutagenesis study. The confirmed binding mode between this novel covalent antagonist and $\mathrm{hA}_{3} \mathrm{AR}$ opens the door for exploring other ligand binding motifs and will benefit receptor stabilization and further structure elucidation of the $h A_{3} \mathrm{AR}$.

\section{RESULTS AND DISCUSSION}

Design of Covalent $\mathrm{hA} A \mathrm{~A}$ Antagonists. In previous studies, our research group disclosed several series of $\mathrm{hA}_{3} \mathrm{AR}$ antagonists based on the pyrido[2,1-f]purine-2,4-dione scaffold. $^{6-8}$ Using compound $\mathbf{1}$, a nanomolar probe from the previous series, as the starting point, we further designed and synthesized compounds based on a previously suggested binding mode of the pyrido[2,1-f]purine-2,4-dione scaffold. When examining the suggested binding mode of this scaffold, we noted that this scaffold inserted into the binding pocket with a receptor interaction between TM3, TM6, and EL2. Two key H-bonds include the carbonyl-oxygen at the $\mathrm{C}^{4}$-position with residue $\mathrm{N} 250^{6.55}$ and the methoxy substituent at the $\mathrm{C}^{8}$ position bonding to $\mathrm{Q} 167^{\mathrm{EL} 2}$. Taking this into account, we reasoned that the only available space to incorporate the reactive warhead is limited to $\mathrm{N}^{1}$-position substituents.

To explore the chemical space required to optimally position the warhead in close proximity to a nucleophilic amino acid residue, we examined various linker systems, connecting the warhead and the pyrido[2,1-f]purine-2,4-dione scaffold. First, variation in the length of the spacer, between two and four carbon atoms, may offer more steric freedom allowing the fluorosulfonyl group to orient toward an adjacent nucleophilic residue in the receptor binding site. ${ }^{15,16}$ Additionally, the type of chemical bond connecting the warhead to the spacer was varied between the slightly differently oriented ester or amide 
Scheme 3. Synthetic Route toward the Amide-Linker Antagonists 17a-c, 18a-c, and $19^{a}$

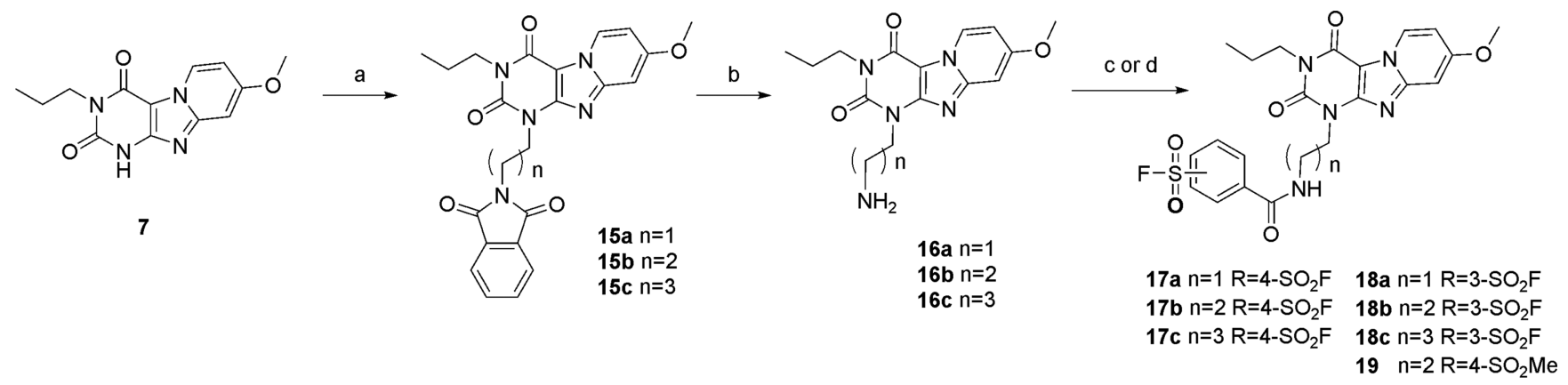

${ }^{a}$ Reagents and conditions: (a) N-(bromoalkyl)phthalimide, $\mathrm{K}_{2} \mathrm{CO}_{3}$, DMF, $100{ }^{\circ} \mathrm{C}$, 5-96\%; (b) $\mathrm{N}_{2} \mathrm{H}_{4} \cdot \mathrm{H}_{2} \mathrm{O}, \mathrm{MeOH}$ reflux, 86-90\%; (c) 1-ethyl-3(3-dimethylaminopropyl)carbodiimide (EDC), corresponding acid (9a,b), $\mathrm{CHCl}_{3}$ or $\mathrm{CH}_{2} \mathrm{Cl}_{2}, \mathrm{rt}$; and (d) $\mathrm{SOCl}_{2}, \mathrm{~K}_{2} \mathrm{CO}_{3}, \mathrm{dry} \mathrm{DMF}^{\circ}, 40{ }^{\circ} \mathrm{C}, 3-78 \%$

Table 1. Apparent Affinities of Pyrido[2,1-f]purine-2,4-dione Derivatives 13-19

\begin{tabular}{|c|c|c|c|c|}
\hline compound & $n$ & $\mathrm{x}$ & $\mathrm{R}^{1}$ & $\mathrm{p} K_{\mathrm{i}} \pm \mathrm{SEM}^{a}$ or disp. at $10 \mu \mathrm{m}(\%)$ \\
\hline $13 a$ & 1 & $\mathrm{O}$ & $4-\mathrm{SO}_{2} \mathrm{~F}$ & $6.7 \pm 0.1$ \\
\hline $13 b$ & 2 & $\mathrm{O}$ & $4-\mathrm{SO}_{2} \mathrm{~F}$ & $7.7 \pm 0.1$ \\
\hline $13 c$ & 3 & $\mathrm{O}$ & $4-\mathrm{SO}_{2} \mathrm{~F}$ & $7.5 \pm 0.1$ \\
\hline $14 a$ & 1 & $\mathrm{O}$ & $3-\mathrm{SO}_{2} \mathrm{~F}$ & $6.4 \pm 0.1$ \\
\hline $14 b$ & 2 & $\mathrm{O}$ & $3-\mathrm{SO}_{2} \mathrm{~F}$ & $7.0 \pm 0.05$ \\
\hline $14 \mathrm{c}$ & 3 & $\mathrm{O}$ & $3-\mathrm{SO}_{2} \mathrm{~F}$ & $7.1 \pm 0.05$ \\
\hline $17 \mathrm{a}$ & 1 & $\mathrm{NH}$ & $4-\mathrm{SO}_{2} \mathrm{~F}$ & $27 \%$ \\
\hline 17b (LUF7602) & 2 & $\mathrm{NH}$ & $4-\mathrm{SO}_{2} \mathrm{~F}$ & $8.0 \pm 0.05$ \\
\hline $17 \mathrm{c}$ & 3 & $\mathrm{NH}$ & $4-\mathrm{SO}_{2} \mathrm{~F}$ & $7.5 \pm 0.05$ \\
\hline $18 \mathrm{a}$ & 1 & $\mathrm{NH}$ & $3-\mathrm{SO}_{2} \mathrm{~F}$ & $18 \%$ \\
\hline $18 b$ & 2 & $\mathrm{NH}$ & $3-\mathrm{SO}_{2} \mathrm{~F}$ & $7.5 \pm 0.01$ \\
\hline $18 \mathrm{c}$ & 3 & $\mathrm{NH}$ & $3-\mathrm{SO}_{2} \mathrm{~F}$ & $6.8 \pm 0.1$ \\
\hline 19 (LUF7714) & 2 & $\mathrm{NH}$ & $4-\mathrm{SO}_{2} \mathrm{Me}$ & $6.3 \pm 0.03$ \\
\hline
\end{tabular}

${ }^{a}$ Data are expressed as means \pm standard error of the mean (SEM) of three separate experiments each performed in duplicate. Apparent affinity determined from the displacement of specific $\left[{ }^{3} \mathrm{H}\right] \mathrm{PSB}-11$ binding from the $\mathrm{hA} \mathrm{A}_{3} \mathrm{AR}$ stably expressed on Chinese hamster ovary (CHO) cell membranes at $25{ }^{\circ} \mathrm{C}$ during $2 \mathrm{~h}$ of incubation.

bond. Finally, since the exact position of an appropriate nucleophilic residue is unknown, the sulfonyl fluoride moiety was positioned at either the 3- or 4-position of the phenyl ring. To this end, four series of compounds $13 a-c, 14 a-c, 17 a-c$, and $18 \mathrm{a}-\mathbf{c}$, bearing three different spacer lengths, ester or amide linkage, and 3- or 4-fluorosulfonylphenyl warhead were targeted for synthesis.

Synthesis. Scaffold. The scaffold, 8-methoxy-3-propyl$1 \mathrm{H}, 3 \mathrm{H}$-pyrido-[2,1-f]purine-2, 4-dione (1), was synthesized according to the previously published procedure. ${ }^{6-8}$ Starting from the commercially available benzylurea (3), the fused tricyclic intermediate (6) was generated by excess $N$ bromosuccinimide (NBS) bromination and 4-methoxypyridine cyclization (Scheme 1). Then, alkylation at the $\mathrm{N}^{3}$-nitrogen by 1-bromopropane in dry dimethylformamide (DMF), using dry potassium carbonate as a weak base, afforded the reference compound (1) in $73 \%$ yield. Removing the benzyl protecting group by palladium hydroxide afforded the fused xanthine core (7).

Ester Linker. The fluorosulfonyl warhead is notorious for its reactivity, resulting in undesired side reactions or hydrolysis under several harsh reactions. ${ }^{17}$ So, we adopted a convergent synthetic strategy in which the fluorosulfonylphenyl linker unit was prepared separately and attached directly to scaffold 7 at the $\mathrm{N}^{3}$ position. This approach offers flexibility to accommodate a variety of different linker lengths. The warhead was synthesized from commercially available chlorosulfonylbenzoic acids ( $\mathbf{8 a}$ and $\mathbf{8 b}$ ) (Scheme 2), followed by a $2 \mathrm{M}$ solution of potassium bifluoride treatment to afford fluorosulfonylbenzoic acids $(\mathbf{9 a}$ and $\mathbf{9 b})$ in good yields. ${ }^{18}$ The next step converted the carboxylic acids to acid chlorides (10a and 10b) by excess thionyl chloride treatment. These acyl chlorides are susceptible to hydrolysis and were thus used in the next step reaction without further purification. To incorporate the acyl chlorides with the corresponding bromoalkylalcohols, compounds 10a and $10 \mathrm{~b}$ were heated to $100{ }^{\circ} \mathrm{C}$ with the addition of bromoalkylalcohols to afford the desired bromoalkyl fluorosulfonylbenzoates $(11 a-c$ and $12 a-c)$ in decent yields. The final step was to couple the core to the corresponding bromoalkyl fluorosulfonylbenzoates. To preserve the functional fluorosulfonyl group, the reactions were carried out under mild conditions at low temperatures. Additionally, 
Table 2. (Apparent) Affinities of $17 \mathrm{~b}$ and 19 for All Adenosine Receptor Subtypes, hA $\mathrm{A}_{3} \mathrm{AR}-\mathrm{WT}$, and hA $\mathrm{AR}_{3} \mathrm{Y}_{265 F^{7.36} a}$

\begin{tabular}{|c|c|c|c|c|c|c|c|}
\hline \multirow{3}{*}{$\begin{array}{l}\text { cpd } \\
17 b^{i}\end{array}$} & $\mathrm{hA}_{1} \mathrm{AR}^{b}$ & $\mathrm{hA}_{2 \mathrm{~A}} \mathrm{AR}^{c}$ & \multirow{3}{*}{$\begin{array}{c}\mathrm{hA}_{2 \mathrm{~B}} \mathrm{AR}^{d} \\
\text { displ. }(\%) \text { at } 1 \mu \mathrm{m} \\
0 \%(7,-7)\end{array}$} & \multicolumn{2}{|c|}{$\mathrm{hA}_{3} \mathrm{AR}$} & $\mathrm{hA}_{3} \mathrm{AR}-\mathrm{WT}^{\mathrm{g}}$ & $\mathrm{A}_{3} \mathrm{AR}-\mathrm{Y} 265 \mathrm{~F}^{7.36 h}$ \\
\hline & \multicolumn{2}{|c|}{$\mathrm{p} K_{\mathrm{i}} \pm \mathrm{SEM}$} & & \multirow{2}{*}{$\begin{array}{c}\mathrm{p} K_{\mathrm{i}}^{e}(\text { pre-0 h) } \\
6.9 \pm 0.06\end{array}$} & \multirow{2}{*}{$\begin{array}{c}\mathrm{p} K_{\mathrm{i}}^{f}(\mathrm{pre}-4 \mathrm{~h}) \\
8.0 \pm 0.01^{* *}\end{array}$} & \multicolumn{2}{|c|}{$\mathrm{pIC}_{50} \pm \mathrm{SEM}^{f}$} \\
\hline & $6.1 \pm 0.03$ & $5.9 \pm 0.09$ & & & & $7.8 \pm 0.05$ & $6.0 \pm 0.3^{*}$ \\
\hline 19 & $4.8 \pm 0.20$ & $5.2 \pm 0.20$ & $0 \%(-10,-13)$ & $6.2 \pm 0.03$ & $6.1 \pm 0.06^{\mathrm{NS}}$ & $5.9 \pm 0.02$ & $6.1 \pm 0.1^{\mathrm{NS}}$ \\
\hline
\end{tabular}

${ }^{a}$ Values represent mean \pm SEM of three separate experiments, each performed in duplicate, or percentage displacement at $1 \mu \mathrm{m}$ of two separate experiments, each performed in duplicate. ${ }^{b}$ Affinity determined from the displacement of specific $\left[{ }^{3} \mathrm{H}\right] \mathrm{DPCPX}$ binding on CHO cell membranes stably expressing human adenosine $\mathrm{A}_{1}$ receptors at $25{ }^{\circ} \mathrm{C}$ during $2 \mathrm{~h}$ of incubation. ${ }^{c}$ Affinity determined from the displacement of specific $\left[{ }^{3} \mathrm{H}\right]$ ZM241385 binding on HEK293 cell membranes stably expressing human adenosine $\mathrm{A}_{2 \mathrm{~A}}$ receptors at $25^{\circ} \mathrm{C}$ during $2 \mathrm{~h}$ of incubation. ${ }^{d_{\%}}$ displacement at $1 \mu \mathrm{m}$ concentration of specific $\left[{ }^{3} \mathrm{H}\right] \mathrm{PSB}-603$ binding on $\mathrm{CHO}$ cell membranes stably expressing human adenosine $\mathrm{A}_{2 \mathrm{~B}}$ receptors at $25{ }^{\circ} \mathrm{C}$ during $2 \mathrm{~h}$ of incubation. ${ }^{e}$ Displacement of specific $\left[{ }^{3} \mathrm{H}\right] \mathrm{PSB}-11$ binding on $\mathrm{CHO}$ cell membranes stably expressing the $\mathrm{hA} \mathrm{AR}^{\mathrm{A}}$ at $25{ }^{\circ} \mathrm{C}$ during $0.5 \mathrm{~h}$ of incubation. ${ }^{f}$ Displacement of specific $\left[{ }^{3} \mathrm{H}\right] \mathrm{PSB}-11$ binding from $\mathrm{CHO}$ cell membranes stably expressing the hA ${ }_{3} \mathrm{AR}$ preincubated with an antagonist for $4 \mathrm{~h}$ at $25{ }^{\circ} \mathrm{C}$, followed by a $0.5 \mathrm{~h}$ of co-incubation with $\left[{ }^{3} \mathrm{H}\right] \mathrm{PSB}-11 . P<0.01 * *$ compared with the pK $K_{\mathrm{i}}$ values in displacement experiments during $0.5 \mathrm{~h}$ of incubation time; NS: no significant difference compared with the $\mathrm{p} K_{\mathrm{i}}$ values in displacement experiments during $0.5 \mathrm{~h}$ of incubation time; Student's test. ${ }^{g}$ Displacement of specific $\left[{ }^{3} \mathrm{H}\right] \mathrm{PSB}-11$ binding from CHO-K1 cell membranes transiently transfected with $\mathrm{hA}_{3} \mathrm{AR}-\mathrm{WT}$ at $25{ }^{\circ} \mathrm{C}$ during $2 \mathrm{~h}$ of incubation. ${ }^{h}$ Displacement of specific $\left[{ }^{3} \mathrm{H}\right] \mathrm{PSB}-11$ binding from CHO-K1 cell membranes transiently transfected with $\mathrm{hA}_{3} \mathrm{AR}-\mathrm{Y} 265 \mathrm{~F}^{7.36}$ at $25^{\circ} \mathrm{C}$ during $2 \mathrm{~h}$ of incubation. $P<0.01^{*}$ compared with the pIC $\mathrm{C}_{50}$ values in displacement experiments on $\mathrm{hA}_{3} \mathrm{AR}-\mathrm{WT}$. NS: no significant difference compared with the $\mathrm{pIC}_{50}$ values in displacement experiments on $\mathrm{hA} \mathrm{A}_{3} \mathrm{AR}-\mathrm{WT}$ membranes; Student's test. ${ }^{i}$ For $\mathbf{1 7} \mathbf{b}, \mathrm{p} K_{\mathrm{i}}$ values are apparent affinity values as no dynamic equilibrium can be obtained.
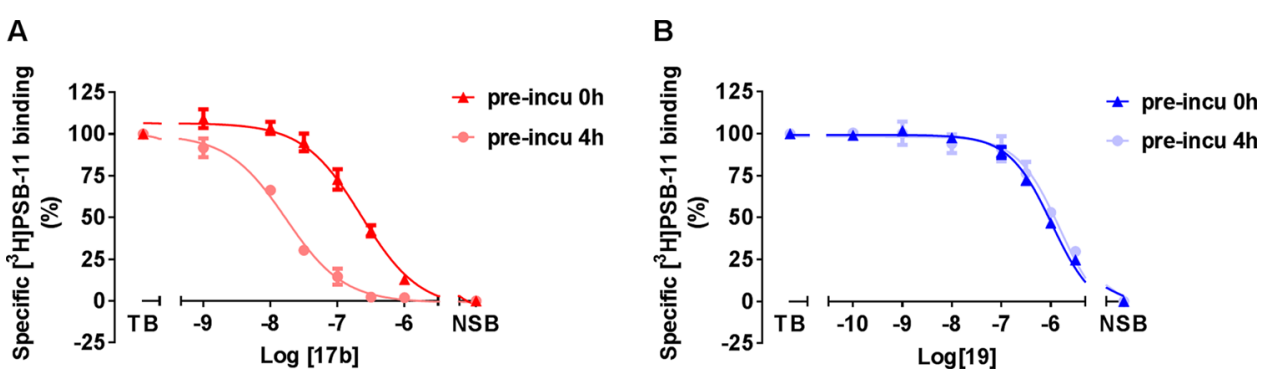

Figure 2. (A) Displacement of $\left[{ }^{3} \mathrm{H}\right] \mathrm{PSB}-11$ binding from the $\mathrm{hA} \mathrm{A}_{3} \mathrm{AR}$ at $25^{\circ} \mathrm{C}$ by $\mathbf{1 7 b}$ with and without preincubation of $4 \mathrm{~h}$. (B) Displacement of $\left[{ }^{3} \mathrm{H}\right]$ PSB-11 binding from the $\mathrm{hA}_{3} \mathrm{AR}$ at $25{ }^{\circ} \mathrm{C}$ by 19 with and without preincubation of $4 \mathrm{~h}$. Data represent the mean \pm SEM of three individual experiments performed in duplicate.

excess DMF was removed by multiple washing steps, instead of vacuum removal at high temperatures. Six final products $(13 a-c$ and $14 a-c)$ were obtained in acceptable yields.

Amide Linker. A similar synthetic approach was initially pursued to prepare analogues with an amide linker. However, the basicity and instability of bromoalkylamine caused complex side reactions with itself and with the warhead, ending up with an unacceptably low yield of amide-linked building blocks. An alternative synthetic route was devised, where 1-phthalimidopropyl bromide was attached directly to the $\mathrm{N}^{3}$ position of scaffold 6, to afford the substituted intermediates $15 a-c$ (Scheme 3). Liberation of the amine took place by treatment with hydrazine monohydrate in methanol to obtain compound $16 a-c$ in moderate yield. Then $16 b$ and $16 c$ were acylated with acyl chlorides $10 a$ and $10 b$, respectively, to obtain $17 \mathrm{c}$ and $\mathbf{1 8 b}$. However, impurities brought by the acylation reaction were not easily removed by column chromatography or preparative thin-layer chromatography (TLC). To overcome this, we used peptide coupling conditions with the corresponding benzoic acids (9a and $\mathbf{9 b}$ ) to convert the free amine to the target compounds $(\mathbf{1 7 a}, \mathbf{b}, \mathbf{1 8 a}$, and $18 \mathrm{c})$ in good yields (Scheme 3). A similar synthetic strategy was adapted to obtain reversible ligand $\mathbf{1 9}$ as a control compound.

Pharmacological Evaluation. Determination of the Apparent Affinity $\left(K_{i}\right)$ of Synthetized Ligands. To determine the binding affinity for the $\mathrm{hA}_{3} \mathrm{AR}$, all compounds were tested in a radioligand displacement binding assay in the presence of $10 \mathrm{nM}\left[{ }^{3} \mathrm{H}\right] \mathrm{PSB}-11$ at $25{ }^{\circ} \mathrm{C}$ according to previously reported procedures. $^{7,19}$ All compounds were able to concentration- dependently inhibit specific $\left[{ }^{3} \mathrm{H}\right] \mathrm{PSB}-11$ binding to the $\mathrm{hA}_{3} \mathrm{AR}$. As detailed in Table 1, all putative covalent compounds, except the two carbon linker compounds (13a, 14a, 17a, and 18a), displayed high affinities for the $\mathrm{hA}_{3} \mathrm{AR}\left(K_{\mathrm{i}}\right.$ $<100 \mathrm{nM}$ ). It should be mentioned that the putative covalent nature of the interaction between the $\mathrm{hA}_{3} \mathrm{AR}$ and ligands precludes the determination of equilibrium binding parameters. Therefore, we expressed the ligands' affinity for the

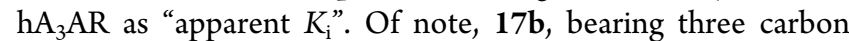
atoms with amide linkage and positioning the sulfonyl fluoride at the 4-position of the phenyl ring, interacted with the $\mathrm{hA}_{3} \mathrm{AR}$ with comparable affinity $(10 \mathrm{nM})$ as the parent compound $\mathbf{1}$. High affinity is desirable for covalent ligand design, as it allows sufficient receptor occupancy with the electrophilic warhead in proximity to a nucleophilic residue in the binding site over time, concomitant with putatively negligible or less interaction with off-targets. Thus, we chose compound $\mathbf{1 7 b}$ for further studies. However, featuring an electrophilic fluorosulfonyl functionality, $\mathbf{1 7 b}$ was no longer a close analogue of compound 1, whereas a nonreactive control compound, chemically similar to the designed covalent ligand, is needed for the further pharmacological characterization.

A nonsubstituted phenyl to replace the warhead might impose different steric and electronic characteristics of the ligand. To avoid this, we performed a conservative structural modification to replace the reactive warhead with an electronwithdrawing methylsulfonyl group, yielding derivative 19 as a nonreactive control compound. 
To better understand the time-dependent binding characteristics of these compounds, we carried out radioligand displacement assays under two different protocols. In detail, the $\mathrm{CHO}$ cell membranes overexpressing the $\mathrm{hA} \mathrm{A}_{3} \mathrm{AR}$ were either preincubated with the indicated compound for $4 \mathrm{~h}$, followed by a $0.5 \mathrm{~h}$ co-incubation or only co-incubated for 0.5 $\mathrm{h}$ with the radioligand $\left[{ }^{3} \mathrm{H}\right] \mathrm{PSB}-11$. As detailed in Table 2, both compounds had comparable binding affinity in the low micromolar range $\left(\mathrm{p} K_{\mathrm{i}}=6.9 \pm 0.06\right.$ for $17 \mathrm{~b}$ and $\mathrm{p} K_{\mathrm{i}}=6.2 \pm$ 0.03 for 19$)$ at $0.5 \mathrm{~h}$ incubation time. However, compound $17 \mathrm{~b}$ showed a significantly increased affinity $\left(\mathrm{p} K_{\mathrm{i}}=8.0 \pm 0.01\right)$ when it was preincubated with the $\mathrm{hA}_{3} \mathrm{AR}$, whereas the affinity of compound 19 did not change $\left(\mathrm{p} K_{\mathrm{i}}=6.1 \pm 0.06\right)$. The effect of preincubation on the affinity of $\mathbf{1 7 b}$ and 19 is illustrated in Figure 2, i.e., the $\left[{ }^{3} \mathrm{H}\right] \mathrm{PSB}-11$ displacement curve was shifted to the left with an increased incubation time for compound 17b (Figure 2A), whereas no difference was observed for compound 19 (Figure 2B).

Presumably, this time-dependent binding affinity of compound $\mathbf{1 7 b}$ (i.e., resulting from an increased receptor occupancy over time) is a result of an increasing level of covalent binding. Similar results on other GPCRs, such as $\beta_{2}$ adrenergic receptor ${ }^{20}$ and $\mathrm{A}_{2 \mathrm{~A}}$ adenosine receptor, ${ }^{21}$ showed that covalent bond formation generates an increased affinity over time. Meanwhile, control compound 19 showed no substantial $\mathrm{p} K_{\mathrm{i}}$ shift in affinity at the two incubation times, indicating that a dynamic equilibrium was achieved at both incubation times. We can thus speculate that the possible covalent interaction between compound $\mathbf{1 7 b}$ and the receptor may be attributed to the presence of a reactive warhead.

Finally, we tested $\mathbf{1 7 b}$ and $\mathbf{1 9}$ for their affinity on the other adenosine receptor subtypes and learned that the two compounds were at least modestly selective for the $h A_{3} \mathrm{AR}$ (Table 2).

Kinetic Characterization of the Covalent Ligand. Subsequently, the significant shift in apparent $K_{\mathrm{i}}$ drove us to explore the binding kinetic profile of $\mathbf{1 7 b}$ at the $h \mathrm{~A}_{3} \mathrm{AR}$, specifically its dissociation rate and residence time (RT). Previously, the $k_{\text {on }}\left(k_{1}=0.281 \pm 0.04 \times 10^{8} \mathrm{M}^{-1} \mathrm{~min}^{-1}\right)$ and $k_{\text {off }}\left(k_{2}=0.3992 \pm 0.02 \mathrm{~min}^{-1}\right)$ values of $\left[{ }^{3} \mathrm{H}\right] \mathrm{PSB}-11$ at $25^{\circ} \mathrm{C}$ had been determined in our laboratory by traditional association and dissociation assays. Here, we performed a competition association assay to characterize the binding kinetics of $17 \mathrm{~b}$ and 19 following previously reported procedures from our research group. ${ }^{7}$ Using the on- and offrate constants from $\left[{ }^{3} \mathrm{H}\right] \mathrm{PSB}$, the $k_{\text {on }}\left(k_{3}\right)$ and $k_{\text {off }}\left(k_{4}\right)$ values for $17 \mathbf{b}$ were determined using the equations from the (equilibrium) Motulsky and Mahan model. ${ }^{22} 17 \mathbf{b}$ had a much slower association rate $\left(k_{\mathrm{on}}=3.48 \pm 0.22 \times 10^{5} \mathrm{M}^{-1} \min ^{-1}\right)$ than the radioligand and a negligible dissociation rate $\left(k_{\text {off }}=\right.$ $\left.1.38 \pm 0.22 \times 10^{-12} \mathrm{~min}^{-1}\right)$, yielding an almost infinite residence time $\left(\mathrm{RT}=7.63 \pm 1.19 \times 10^{11} \mathrm{~min}\right)$, indicative of irreversible receptor binding by $\mathbf{1 7} \mathbf{b}$. The inadequacy of the Motulsky-Mahan equations to fit this data is further evidence for the nonequilibrium features of the binding of $17 \mathbf{b}$ to the receptor. Compound 19 showed fast association and dissociation rate constants (Figure 3). Unfortunately, the data did not converge in the fitting procedure, possibly due to the low binding affinity of compound $19\left(K_{\mathrm{i}}=525 \mathrm{nM}\right)$.

As detailed in Figure 3, the control curve represented the association curve of radioligand $\left[{ }^{3} \mathrm{H}\right] \mathrm{PSB}-11$ alone, approaching equilibrium over time. Compound 19 equally associated with and dissociated from the receptor and reached

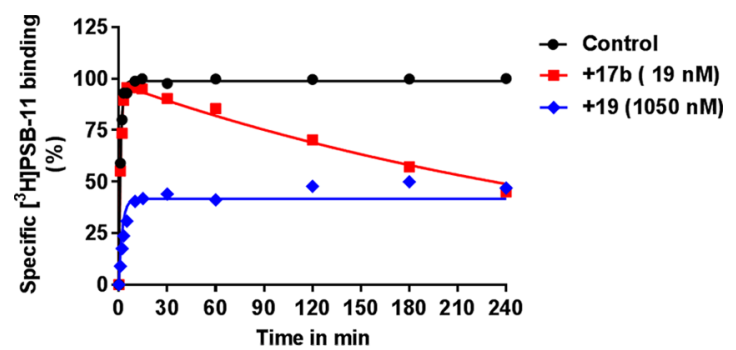

Figure 3. Competition association assay of $\left[{ }^{3} \mathrm{H}\right] \mathrm{PSB}-11$ in the absence (control) or presence of $17 \mathrm{~b}$ and 19 at the indicated concentration. Association and dissociation rate constants for the unlabeled ligands were calculated by fitting the data to the equations described in the Experimental Section ("data analysis"). Representative graphs are from one experiment performed in duplicate.

equilibrium within $30 \mathrm{~min}$, evidenced by the same curve shape as the control curve. Of note, $\mathbf{1 7 b}$ 's behavior caused an initial "overshoot" of the competition association curve, followed by a linear decline over time indicating that no equilibrium was reached. The shape of $\mathbf{1 7 b}$ 's kinetic curve is a quintessential example for the irreversible interaction, similar to the reported covalent ligands' behavior for the adenosine $\mathrm{A}_{2 \mathrm{~A}}$ receptor $^{21}$ and mGlu2 receptor. ${ }^{23}$

Wash-Resistant Interaction between $17 b$ and $h A_{3} A R$. Inspired by the negligible dissociation of compound $17 \mathrm{~b}$ from the $\mathrm{hA}_{3} \mathrm{AR}$, we performed a "washout" experiment to ascertain the irreversible binding between the ligand and the receptor. A protocol previously reported by our laboratory ${ }^{21}$ was adapted. We first exposed $h A_{3} A R$ cell membranes to $17 \mathrm{~b}$ or 19 both at 10 -fold $K_{\mathrm{i}}$ for $2 \mathrm{~h}$, and without washing the samples were supplemented with $\left[{ }^{3} \mathrm{H}\right] \mathrm{PSB}-11$ to assess the competitive binding capacity of the receptor ("control group" in Figure 4).

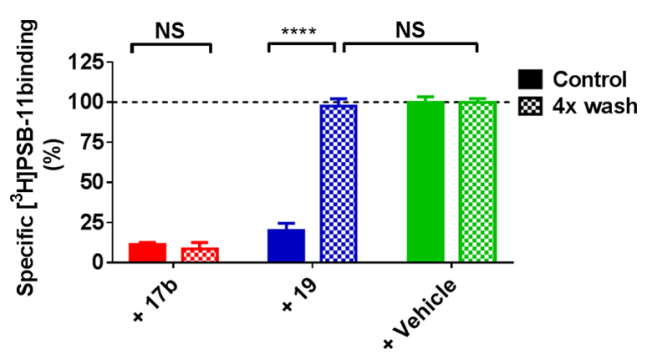

Figure 4. $h A_{3} \mathrm{AR}$ membranes preincubated with buffer (vehicle) or a $10 \times K_{\mathrm{i}}$ concentration of indicated ligand, followed by no washing (control) or four-cycle washing treatment ( $4 \times$ wash) before being exposed to $\left[{ }^{3} \mathrm{H}\right] \mathrm{PSB}-11$. Data represent the mean \pm SEM of three individual experiments performed in duplicate, normalized to the vehicle (set at 100\%). Statistics were determined using unpaired Student's $t$-test. NS: no significant difference, $* * * * P<0.0001$, significant difference between indicated groups.

For washed samples, $\mathrm{hA}_{3} \mathrm{AR}$ cell membranes were subjected to four-cycle washing steps to remove unbound ligand following the preincubation ("4× wash group" in Figure 4), after which the membranes were exposed to $\left[{ }^{3} \mathrm{H}\right] \mathrm{PSB}-11$ to determine the remaining binding capacity. In the absence of the ligand (labeled “+ vehicle” in Figure 4), we normalized membranes' binding ability to $100 \%$. Following preincubation with $\mathbf{1 7 b}$, membranes containing the $\mathrm{hA}_{3} \mathrm{AR}$ lost most of the ability to bind to the radioligand $(11.3 \pm 1.2 \%$ binding remaining). Furthermore, after the preincubation, membranes were washed by cycles of centrifugation in an attempt to regenerate binding 
A

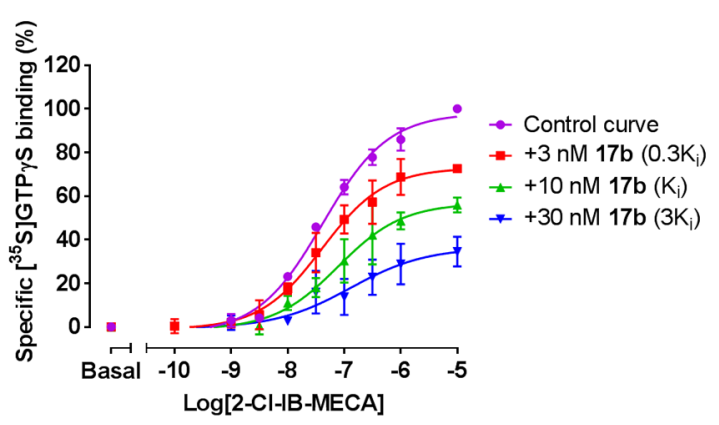

C

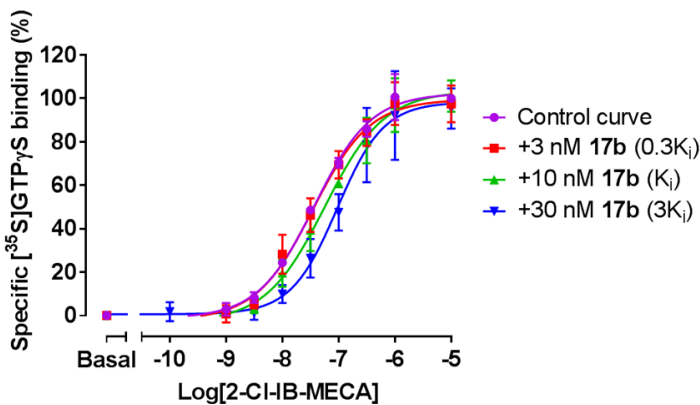

B

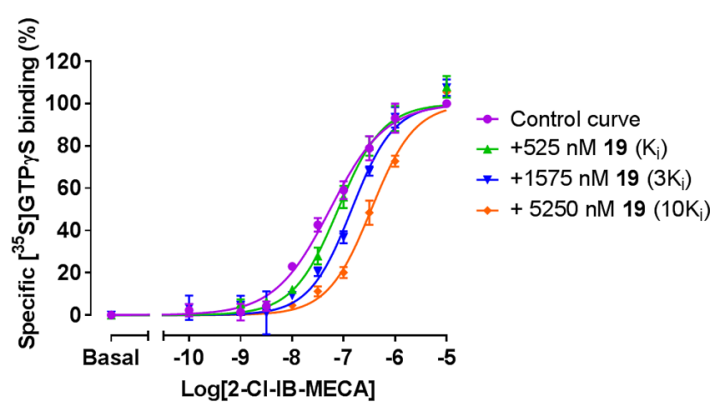

D

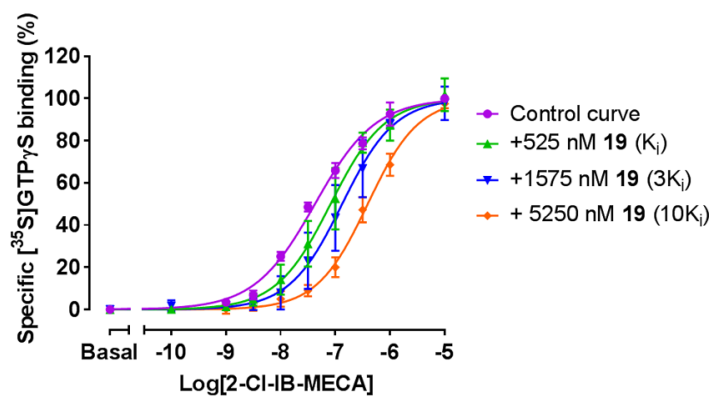

Figure 5. Effects of $17 \mathrm{~b}$ and 19 on $\mathrm{hA}_{3} \mathrm{AR}$ activation as measured by $\left[{ }^{35} \mathrm{~S}\right] \mathrm{GTP} \gamma \mathrm{S}$ binding. (A, B) Compound $\mathbf{1 7 b}(\mathrm{A})$ or 19 (B) was preincubated with the $\mathrm{hA}_{3} \mathrm{AR}$ stably expressed on $\mathrm{CHO}$ cell membranes $\left(25^{\circ} \mathrm{C}\right)$ for $60 \mathrm{~min}$ prior to the addition of 2-Cl-IB-MECA at a concentration ranging from $0.1 \mathrm{nM}$ to $10 \mu \mathrm{m}$ for $30 \mathrm{~min}$. (C, D) Compound $17 \mathrm{~b}$ (C) or 19 (D) were co-incubated with 2-Cl-IB-MECA, at a concentration ranging from $0.1 \mathrm{nM}$ to $10 \mu \mathrm{m}$, for $30 \mathrm{~min}$. The agonist curves were generated in the presence of increasing concentrations of antagonists, such as 0.3-, 1-, 3-, and 10 -fold $K_{\mathrm{i}}$ values, respectively. Data are from three independent experiments performed in duplicate, normalized according to the maximal response $(100 \%)$ produced by $10 \mu \mathrm{m}$ 2-Cl-IB-MECA alone. The shift in agonist $\mathrm{EC}_{50}$ values was determined to perform Schild analyses.

Table 3. Functional Analysis of $\mathrm{hA}_{3} \mathrm{AR}$ Antagonism from $\left[{ }^{35} \mathrm{~S}\right] \mathrm{GTP} \gamma \mathrm{S}$ Binding Assays ${ }^{a}$

\begin{tabular}{|c|c|c|c|c|c|}
\hline \multirow[b]{2}{*}{ compound } & \multicolumn{2}{|c|}{ preincubation } & \multicolumn{2}{|c|}{ co-incubation } & \multirow[b]{2}{*}{ mode of antagonism } \\
\hline & $\mathrm{p} A_{2}$ & Schild slope & $\mathrm{p} A_{2}$ & Schild slope & \\
\hline $17 \mathbf{b}$ & NA & NA & $7.4 \pm 0.1$ & $1.1 \pm 0.1$ & competitive insurmountable \\
\hline 19 & $5.9 \pm 0.1$ & $1.1 \pm 0.1$ & $6.2 \pm 0.1$ & $1.0 \pm 0.1$ & competitive surmountable \\
\hline
\end{tabular}

${ }^{a}$ Values represent mean \pm SEM of three separate experiments each performed in duplicate.

capacity. However, washing steps failed to restore $\mathrm{hA}_{3} \mathrm{AR}$ binding of $\left[{ }^{3} \mathrm{H}\right]$ PSB-11 $(8.7 \pm 3.8 \%)$. This was in contrast to preincubation of the $\mathrm{hA}_{3} \mathrm{AR}$-expressing membranes with ligand 19, in which binding function was completely restored from $19.8 \pm 4.7$ to $97.6 \pm 4.5 \%$ following four washing steps. This result indicates that 19 is a reversible ligand which can be rapidly washed off the membranes, whereas $\mathbf{1 7} \mathbf{b}$ forms a washresistant bond between the ligand and the receptor. Similar experiments on other GPCRs, such as adenosine $A_{1}{ }^{24,25}$ and $\mathrm{A}_{2 \mathrm{~A}}{ }^{21}$ receptors and the metabotropic glutamate receptor 2 (mGluR2), ${ }^{23}$ demonstrated that the covalent interaction between the ligand and the receptor resulted in a washresistant bond formation.

Insurmountable Antagonism Caused by Covalent Interaction. To further evaluate the effect of irreversible inhibition by covalent ligand $\mathbf{1 7 b}$ on receptor function, we performed a membrane functional assay using $\left[{ }^{35} \mathrm{~S}\right] \mathrm{GTP} \gamma \mathrm{S}$, which is a typical readout for the activation of receptor-coupled $G_{i / o}$ proteins. ${ }^{26}$ Pretreatment of the $\mathrm{hA}_{3} \mathrm{AR}$ with increasing concentrations of ligand $17 \mathbf{b}$, prior to the stimulation with $\mathrm{hA}_{3} \mathrm{AR}$ agonist 1-[2-chloro-6-[[(3-iodophenyl)methyl]amino]$9 H$-purin-9-yl]-1-deoxy- $N$-methyl- $\beta$-D-ribofuranuronamide (2-
Cl-IB-MECA), produced rightward shifts of agonist concentration-response curves with a concomitant decline in maximal stimulation (Figure 5A). Therefore, the covalent ligand $17 \mathbf{b}$ generated insurmountable antagonism in the preincubation experiment. In contrast, pretreatment of the $\mathrm{hA}_{3} \mathrm{AR}$ with 19, followed by 2-Cl-IB-MECA agonist exposure resulted in surmountable antagonism (Figure $5 B$ ), i.e., shifting dose-response curves to the right with no alteration of its maximum effect. The extent of the shifts was used to construct a Schild plot as previously described, ${ }^{7}$ which would have a slope of unity if the interaction is competitive and the $\mathrm{p} A_{2}$ value corresponds to the $\mathrm{p} K_{\mathrm{i}}$ value of the antagonist. The slope for 19 was found to be $1.1 \pm 0.1$ and the compound's $\mathrm{p} A_{2}$ value was $5.9 \pm 0.1$, comparable with its $\mathrm{p} K_{\mathrm{i}}$ value $(6.3 \pm$ 0.03 ), suggesting that 19 competed with 2-Cl-IB-MECA for the same receptor binding site.

To unravel the molecular mechanism responsible for the insurmountable antagonism of $\mathbf{1 7} \mathbf{b}$, we also co-incubated either $17 \mathrm{~b}$ or 19 with the $\mathrm{hA}_{3} \mathrm{AR}$ in the presence of 2-Cl-IBMECA. Both ligands produced a rightward shift of the agonist's concentration-response curve (Figure 5C,D) with no suppression of maximal response, indicative of surmountable 


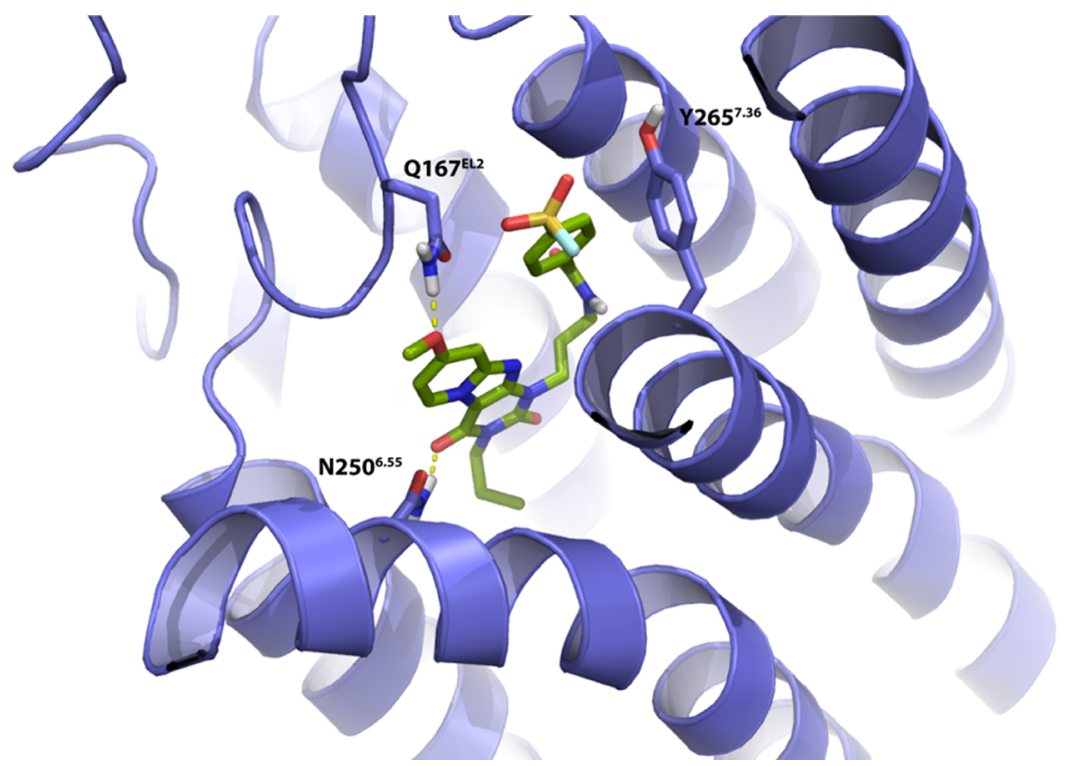

Figure 6. Proposed binding mode of compound $\mathbf{1 7 b}$ (green carbon sticks) in a homology model (violet ribbons) of the $h A_{3} A R$. The $h A_{3} A R$ homology model was based on the high-resolution antagonist-bound crystal structure of the adenosine $A_{2 A}$ receptor (PDB: 4EIY ${ }^{27}$ ). Atom color code: red $=$ oxygen, blue $=$ nitrogen, white $=$ hydrogen, yellow $=$ sulfur, cyan $=$ fluorine Hydrogen bonds between the ligand and receptor are indicated by yellow dashed lines. Residue Y $265^{7.36}$ is in the proximity of the fluorosulfonyl warhead.

A

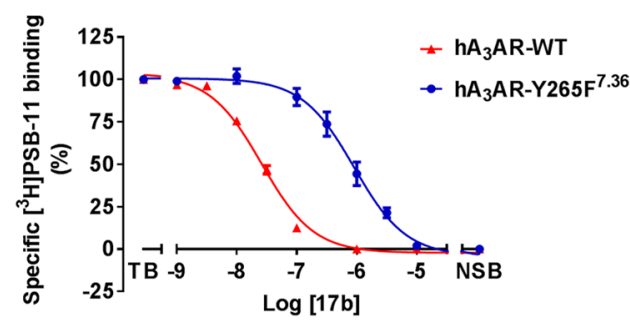

C

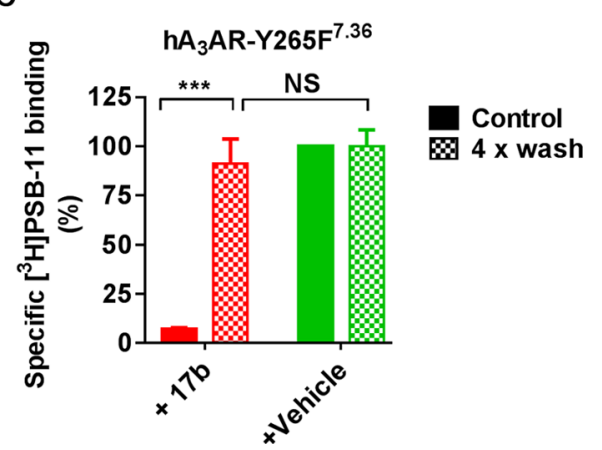

B

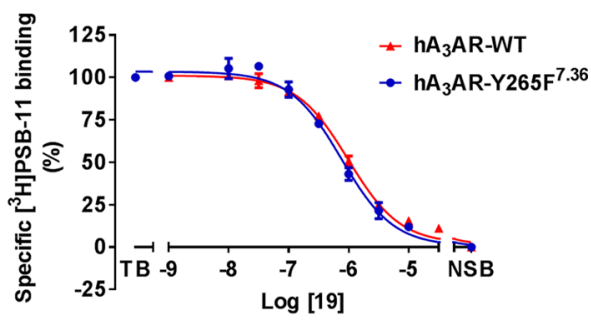

Figure 7. (A, B) Displacement of specific $\left[{ }^{3} \mathrm{H}\right] \mathrm{PSB}-11$ binding from transiently transfected $\mathrm{hA}$ AR-WT and $\mathrm{hA} \mathrm{A}_{3} \mathrm{AR}-\mathrm{Y} 265 \mathrm{~F}^{7.36}$ at $25{ }^{\circ} \mathrm{C}$ by compound $17 \mathrm{~b}(\mathrm{~A})$ and $19(\mathrm{~B})$ during incubation of $2 \mathrm{~h}$. (C) $\mathrm{hA}_{3} \mathrm{AR}-\mathrm{Y} 265 \mathrm{~F}^{7.36}$ cell membranes were pretreated with buffer (vehicle) or $10 \times \mathrm{IC}_{50}$ of compound $17 \mathrm{~b}$ for $2 \mathrm{~h}$ followed by no washing (control) or four-cycle washing treatment ( $4 \times$ wash) before being exposed to [ $\left.{ }^{3} \mathrm{H}\right]$ PSB-11. Data represent the mean \pm SEM of three individual experiments performed in duplicate, normalized to the vehicle (set at $100 \%)$. NS: no significant difference between groups; ***Significant difference between groups $(P<0.001)$; Student's $t$-test.

antagonism. The Schild plot showed that both antagonists inhibited receptor activation in a competitive manner, with their Schild-slopes close to unity $(1.1 \pm 0.1$ for $\mathbf{1 7 b}, 1.0 \pm 0.1$ for 19, Table 3). In addition, 19's $\mathrm{p} A_{2}$ value was in agreement with that from the preincubation experiments $(6.2 \pm 0.1$, Table 3 ), and the $\mathrm{p} A_{2}$ value of $\mathbf{1 7} \mathbf{b}$ was also comparable with its $\mathrm{p} K_{\mathrm{i}}$ value $(7.4 \pm 0.1$ vs $8.0 \pm 0.05)$. Taken together, both ligands fully competed with 2-Cl-IB-MECA bound to the $\mathrm{hA}_{3} \mathrm{AR}$.
Notably, it is likely that the insurmountable behavior relates to the covalent binding of $\mathbf{1 7} \mathbf{b}$ due to an irreversible blockade that reduces the total receptor population available.

Binding Model for $\mathbf{1 7 b}$ in the $h A_{3} A R$ Receptor-Binding Pocket. To examine the interaction between receptor residues possibly involved in covalent binding, we docked $17 \mathbf{b}$ into a ligand optimized homology model on the basis of the $A_{2 A}$ receptor crystal structure (PDB: $\left.4 \mathrm{EIY}^{27}\right)$, as described 
previously. ${ }^{7}$ As detailed in Figure 6, the core structure of compound $17 \mathbf{b}$ interacted with the TM3, TM6, and EL2 regions. Additionally, the carbonyl-oxygen at the $\mathrm{C}^{4}$-position participated in $\mathrm{H}$-bond formation with residue $\mathrm{N} 250^{6.55}$ and the methoxyl moiety at the $\mathrm{C}^{8}$-position functioned as H-bond acceptor with $\mathrm{Q} 167^{\mathrm{EL} 2}$. Interestingly, the latter is a unique residue in the $h \mathrm{~A}_{3} \mathrm{AR}$, as it is not conserved in other subtypes of adenosine receptors. Due to the flexibility of the three carbon linkers, the tyrosine residue $\mathrm{Y} 265^{7.36}$ is in close proximity of the ligand, and could therefore interact with the 4-fluorosulfonylbenzoic warhead to form a covalent sulfonyl amide. Similarly, the same residue Y271 ${ }^{7.36}$ located within the human adenosine $A_{1}$ receptor has also been reported to covalently interact with the fluorosulfonyl warhead of compound 2. ${ }^{11}$ Comparison of the binding modes of compound 2 and ligand $17 \mathrm{~b}$ in an $\mathrm{A}_{1} / \mathrm{A}_{3}$ receptor overlay showed that key interactions between ligands and binding sites are preserved, such as a hydrogen bond with $\mathrm{N}^{6.55}$ (Figure $\mathrm{S} 1$ ).

Y265 $5^{7.36}$ as an Anchor Point for the Covalent Bond. Based on the docking study, we postulated that $\mathrm{Y}^{2} 65^{7.36}$ is the anchor point for covalent bond formation. To investigate our hypothesis this tyrosine was mutated to phenylalanine $\left(\mathrm{hA} \mathrm{A}_{3} \mathrm{AR}-\mathrm{Y} 265 \mathrm{~F}^{7.36}\right)$, to remove the nucleophilic reactivity of the phenolic hydroxyl group. First, we performed standard $\left[{ }^{3} \mathrm{H}\right]$ PSB-11 displacement assays to investigate the binding affinity of $17 \mathrm{~b}$ and 19 using CHO-K1 cell membranes transiently transfected with either wild type $\left(\mathrm{hA}_{3} \mathrm{AR}-\mathrm{WT}\right)$ or mutant receptors $\left(\mathrm{hA}_{3} \mathrm{AR}-\mathrm{Y} 265 \mathrm{~F}^{7.36}\right)$. As shown in Table 2 and Figure 7, the affinity of control compound 19 on $\mathrm{hA}_{3} \mathrm{AR}$ $\mathrm{Y}_{265 \mathrm{~F}^{7.36}}\left(\mathrm{pIC}_{50}=6.09 \pm 0.11\right)$ was similar to the affinity to $\mathrm{hA}_{3} \mathrm{AR}-\mathrm{WT}\left(\mathrm{pIC}_{50}=5.95 \pm 0.03\right)$, indicating that the mutation has no impact on the binding affinity of the reversible ligand. In marked contrast, $\mathbf{1 7 b}$ 's affinity was decreased nearly 43-fold relative to the WT, from an $\mathrm{IC}_{50}$ value of 27 to $1072 \mathrm{nM}$, indicative of the loss of irreversible interaction. Moreover, there were no marked affinity differences on $\mathrm{hA}_{3} \mathrm{AR}-\mathrm{Y} 265 \mathrm{~F}^{7.36}$ between $17 \mathbf{b}$ and 19. This suggests that the chemically dissimilar ligands $17 \mathrm{~b}$ (reactive) and 19 (nonreactive) exhibit a similar binding interaction with $\mathrm{hA}_{3} \mathrm{AR}$ $\mathrm{Y} 265 \mathrm{~F}^{7.36}$. We thus speculate that the amino acid in position 7.36 plays a prominent role in the covalent bond formation between the fluorosulfonyl warhead and the receptor. To support this idea, we repeated the washout assay on $\mathrm{hA}_{3} \mathrm{AR}$ Y265F ${ }^{7.36}$. Membranes treated with $17 \mathbf{b}$ at 10 -fold $\mathrm{IC}_{50}$ inhibited the specific $\left[{ }^{3} \mathrm{H}\right] \mathrm{PSB}-11$ binding to $7.2 \pm 0.6 \%$. After extensive washing, $\mathrm{hA}$ AR-Y265 $\mathrm{F}^{7.36}$ showed a complete recovery of $\left[{ }^{3} \mathrm{H}\right]$ PSB-11 binding to $91 \pm 2 \%$ (Figure $7 \mathrm{C}$ ). This full recovery for mutant $\mathrm{hA}_{3} \mathrm{AR}-\mathrm{Y} 265 \mathrm{~F}^{7.36}$ is in sharp contrast to the findings in the wild-type washout assay (Figure 4), indicating that $\mathrm{Y}_{2} 65 \mathrm{~F}^{7.36}$ completely prevented the washresistant bond formation. In other words, Y265 7.36 is the unique amino acid residue involved in the covalent attachment of 17b's fluorosulfonyl group within the $\mathrm{hA}_{3} \mathrm{AR}$ binding pocket. A similar approach was also adopted to pinpoint the anchor point between covalent probes and other subtypes of GPCRs, such as the adenosine $\mathrm{A}_{2 \mathrm{~A}}$ receptor, ${ }^{21}$ mGlu2 receptor, ${ }^{23}$ and cannabinoid $\mathrm{CB}_{1}$ receptor. ${ }^{28}$

$17 \mathrm{~b}$ can be a useful structural biology tool as it would be expected to stabilize the 7TM domain in its inactive state, thereby potentially facilitating crystallization of the receptor material. This could be highly valuable for the structure elucidation of the $h A_{3} A R$, which up to now remains unreported. Furthermore, understanding the precise molecular interactions between the ligand and the receptor may stimulate the more rational design of novel ligands. Such ligands may have improved receptor subtype selectivity, fewer undesirable side effects, and enhanced potency and efficacy, leading to potentially attractive therapeutic agents that produce their effects by modulating the functionality of the adenosine system. Given that GPCR-targeted covalent drugs went through clinical success across various indications, ${ }^{29}$ our covalent compound $\mathbf{1 7 b}$ may serve as a probe to explore the problematic translation of $\mathrm{hA}_{3} \mathrm{AR}$ ligands into the clinical utility in certain disease states such as eye disorder glaucoma, in which an increased $A_{3}$ adenosine receptor mRNA and protein levels have been detected.

\section{CONCLUSIONS}

By introducing a reactive sulfonyl fluoride warhead onto the 1benzyl-3-propyl- $1 H, 3 H$-pyrido [2,1-f]purine-2,4-dione scaffold, we designed and synthesized a series of novel covalent $\mathrm{hA} \mathrm{A}_{3} \mathrm{AR}$ antagonists. Compound $\mathbf{1 7} \mathbf{b}$ acted as the most potent antagonist, with a time-dependent apparent affinity in the low nanomolar range. Meanwhile, we removed the warhead and inserted a methylsulfonyl moiety into the scaffold, to obtain ligand 19 as a reversible control compound. Ligand $17 \mathrm{~b}$ was then validated as a covalent antagonist through its washresistant nature and insurmountable antagonism in $\left[{ }^{35} \mathrm{~S}\right] \mathrm{GTP} \gamma \mathrm{S}$ binding assays. In silico homology-docking suggested that $\mathrm{Y}^{2} 65^{7.36}$ is responsible for the covalent interaction. Site-directed mutagenesis showed that removal of the nucleophilic tyrosine phenolic hydroxyl group resulted in the complete loss of covalent binding, validating that $\mathrm{Y} 265^{7.36}$ is the only anchor point of reactive covalent ligand $\mathbf{1 7 b}$. The results contribute to a better understanding of pharmacological behaviors caused by covalent interaction with GPCRs. In the end, we developed a structured approach to quickly obtain a well-defined covalent ligand. Besides, we envisioned that a methylsulfonyl replacement would be suitable for providing a nonreactive sulfonyl-bearing control compound. The rational design of covalent probes may have further value in receptor structure elucidation or in new technologies such as affinitybased protein profiling ${ }^{15,30}$ with the perspective of imaging or structurally probing GPCRs.

\section{EXPERIMENTAL SECTION}

Chemistry. All solvents and reagents were purchased from commercial sources and were of analytical grade. Demineralized water is simply referred to as $\mathrm{H}_{2} \mathrm{O}$, and was used in all cases unless stated otherwise (i.e., brine). ${ }^{1} \mathrm{H}$ were recorded on a Bruker AV 400 liquid spectrometer $\left({ }^{1} \mathrm{H}\right.$ NMR, $\left.400 \mathrm{MHz}\right)$ at ambient temperature and ${ }^{13} \mathrm{C}$ NMR spectra were recorded on a Bruker AV 600 liquid spectrometer $\left({ }^{13} \mathrm{C}\right.$ NMR, $\left.125 \mathrm{MHz}\right)$ at indicated temperature. Chemical shifts are reported in parts per million (ppm), using residual solvent as the internal reference in all cases. The values are given in $\delta$ scale. Coupling-constants are reported in $\mathrm{Hz}$ and are designated as $J$. Analytical purity of the final compounds was determined by high-performance liquid chromatography (HPLC) with a Phenomenex Gemini $3 \mu \mathrm{m} \mathrm{C18} 110 \AA$ A column $(50 \times 4.6 \mathrm{~mm}$, $3 \mu \mathrm{m})$, measuring UV absorbance at $254 \mathrm{~nm}$. Sample preparation and the HPLC method were as follows: $0.3-1.0 \mathrm{mg}$ of compound was dissolved in $1 \mathrm{~mL}$ of a 1:1:1 mixture of $\mathrm{MeCN} / \mathrm{H}_{2} \mathrm{O} / \mathrm{tBuOH}$ and eluted from the column within $15 \mathrm{~min}$ at a flow rate of $1.3 \mathrm{~mL} \mathrm{~min}^{-1}$ with a three-component system of $\mathrm{H}_{2} \mathrm{O} / \mathrm{MeCN} / 1 \%$ trifluoroacetyl (TFA) in $\mathrm{H}_{2} \mathrm{O}$. The elution method was set up as follows: 1-4 min isocratic system of $\mathrm{H}_{2} \mathrm{O} / \mathrm{MeCN} / 1 \%$ TFA in $\mathrm{H}_{2} \mathrm{O}, 80: 10: 10$, from the 4th min, a gradient was applied from 80:10:10 to 0:90:10 within 9 $\mathrm{min}$, followed by $1 \mathrm{~min}$ of equilibration at 0:90:10 and $1 \mathrm{~min}$ at 
80:10:10. All final compounds showed a single peak at the designated retention time and are at least $95 \%$ pure. Liquid chromatographymass spectrometry (LC-MS) analyses were performed using a Thermo Finnigan Surveyor-LCQ Advantage Max LC-MS system and a Gemini C18 Phenomenex column $\left(50 \times 4.6 \mathrm{~mm}^{2}, 3 \mu \mathrm{m}\right)$. Highresolution mass spectrometry (HRMS) analyses were performed using a Thermo Scientific LTQ Orbitrap XL Hybrid Ion TrapOrbitrap Mass Spectrometer. The sample preparation was the same as for HPLC and HRMS analyses. The compounds were eluted from the column within $15 \mathrm{~min}$ after injection, with a three-component system of $\mathrm{H}_{2} \mathrm{O} / \mathrm{MeCN} / 0.2 \%$ TFA in $\mathrm{H}_{2} \mathrm{O}$, decreasing polarity of the solvent mixture in time from 80:10:10 to 0:90:10. Thin-layer chromatography (TLC) was routinely performed to monitor the progress of reactions, using aluminum-coated Merck silica gel F254 plates. Purification by column chromatography was achieved using the Grace Davison Davisil silica column material (LC60A 30-200 $\mu \mathrm{m}$ ). Solutions were concentrated using a Heidolph Laborota W8 2000 efficient rotary evaporation apparatus. All reactions in the synthetic routes were performed under a nitrogen atmosphere unless stated otherwise. The procedure for a series of similar compounds is given as a general procedure for all within that series, annotated by the numbers of the compounds.

1-Benzyl-8-methoxy-3-propyl-1H,3H-pyrido[2,1-f]purine2,4-dione (1). ${ }^{7,8}$ To a stirred suspension of $6(6.0 \mathrm{~g}, 19 \mathrm{mmol}, 1.0$ equiv) in $\mathrm{MeCN}(120 \mathrm{~mL})$ were added 1-bromopropane $(5.6 \mathrm{~mL}, 57$ mmol, 3.0 equiv) and $\mathrm{DBU}(50 \mathrm{~mL}, 57 \mathrm{mmol}, 3.0$ equiv). This mixture was stirred at $70{ }^{\circ} \mathrm{C}$ overnight. The conversion of the starting material was confirmed by TLC $\left(2 \% \mathrm{MeOH}\right.$ in $\left.\mathrm{CH}_{2} \mathrm{Cl}_{2}\right)$ and the solvent was removed under vacuum. The residue was suspended in $\mathrm{CH}_{2} \mathrm{Cl}_{2}(200 \mathrm{~mL})$ and the organic phase was washed with $1 \mathrm{M} \mathrm{HCl}$ $(200 \mathrm{~mL}), \mathrm{H}_{2} \mathrm{O}(200 \mathrm{~mL})$, and brine $(200 \mathrm{~mL})$, dried over $\mathrm{MgSO}_{4}$, filtered, and concentrated in vacuo. The crude was purified by column chromatography $\left(0.5 \% \mathrm{MeOH}\right.$ in $\left.\mathrm{CH}_{2} \mathrm{Cl}_{2}\right)$ to obtain 1 as a white solid $(5.0 \mathrm{~g}, 14 \mathrm{mmol}, 73 \%) .{ }^{1} \mathrm{H}$ NMR $\left(400 \mathrm{MHz}, \mathrm{CDCl}_{3}\right): \delta 8.82(\mathrm{~d}$, $J=7.6 \mathrm{~Hz}, 1 \mathrm{H}), 7.58-7.51(\mathrm{~m}, 2 \mathrm{H}), 7.34-7.22(\mathrm{~m}, 3 \mathrm{H}), 6.98(\mathrm{~d}, J=$ $2.0 \mathrm{~Hz}, 1 \mathrm{H}), 6.74(\mathrm{dd}, J=7.4,2.2 \mathrm{~Hz}, 1 \mathrm{H}), 5.36(\mathrm{~s}, 2 \mathrm{H}), 4.04-3.97$ $(\mathrm{m}, 2 \mathrm{H}), 3.92(\mathrm{~s}, 3 \mathrm{H}), 1.76-1.65(\mathrm{~m}, 2 \mathrm{H}), 0.97(\mathrm{t}, J=7.4 \mathrm{~Hz}, 3 \mathrm{H})$

6-Amino-1-benzyl-1,3-dihydropyrimidine-2,4-dione (5). ${ }^{7,8}$ The synthesis of the compounds was performed as adapted from the procedure reported before. ${ }^{7,8}$ Benzylurea (3) (25 g, $167 \mathrm{mmol}, 1.0$ equiv) and 4 (16 g, $191 \mathrm{mmol}, 1.1$ equiv) were dissolved in acetic anhydride $(100 \mathrm{~mL})$. This mixture was stirred at $80^{\circ} \mathrm{C}$ for $2 \mathrm{~h}$. After the mixture was cooled to room temperature, diethyl ether $(150 \mathrm{~mL})$ was added followed by $1 \mathrm{~h}$ of stirring at room temperature. The precipitate was filtered off and suspended in a mixture of $\mathrm{EtOH}(75$ $\mathrm{mL})$ and $\mathrm{H}_{2} \mathrm{O}(150 \mathrm{~mL})$. This mixture was heated to $85^{\circ} \mathrm{C}$ and $3 \mathrm{M}$ $\mathrm{NaOH}$ (aq.) $(50 \mathrm{~mL})$ was added dropwise. After $1 \mathrm{~h}$, the mixture was concentrated and neutralized by the dropwise addition of $\mathrm{HCl}(37 \%)$. The precipitate was filtered off and washed with acetone, obtaining 5 as a white solid ( $9.0 \mathrm{~g}, 42 \mathrm{mmol}, 25 \%) .{ }^{1} \mathrm{H}$ NMR (400 MHz, DMSO$\left.d_{6}\right): \delta 10.42($ brs, $1 \mathrm{H}), 7.48-7.08(\mathrm{~m}, 5 \mathrm{H}), 6.85$ (brs, $\left.2 \mathrm{H}\right), 5.03(\mathrm{~s}$, $2 \mathrm{H}), 4.60(\mathrm{~s}, 1 \mathrm{H})$

1-Benzyl-8-methoxy-1H,3H-pyrido[2,1-f]purine-2,4-dione (6) ${ }^{7,8}$ To the intermediate (5) (9.0 g, $42 \mathrm{mmol}, 1.0$ equiv) and NBS (15 g, $83 \mathrm{mmol}, 2.0$ equiv) was added $\mathrm{MeCN}(100 \mathrm{~mL})$. This mixture was stirred at $80{ }^{\circ} \mathrm{C}$. After $1.5 \mathrm{~h}$, the conversion of the starting material was confirmed by TLC $\left(10 \% \mathrm{MeOH}\right.$ in $\left.\mathrm{CH}_{2} \mathrm{Cl}_{2}\right)$, 4methoxypyridine ( $13 \mathrm{~g}, 125 \mathrm{mmol}, 3.0$ equiv) was added and the reaction mixture was stirred at $80{ }^{\circ} \mathrm{C}$ for $4.5 \mathrm{~h}$. After cooling to room temperature, the precipitate was filtered off and washed with diethyl ether and $\mathrm{MeOH}$, yielding product 6 as a white solid $(8.5 \mathrm{~g}, 26 \mathrm{mmol}$, 64\%). ${ }^{1} \mathrm{H}$ NMR (400 MHz, DMSO- $\left.d_{6}\right): \delta 11.31(\mathrm{br} \mathrm{s}, 1 \mathrm{H}), 8.70(\mathrm{~d}, J$ $=7.2 \mathrm{~Hz}, 1 \mathrm{H}), 7.38-7.16(\mathrm{~m}, 6 \mathrm{H}), 6.90(\mathrm{dd}, J=7.4,2.2 \mathrm{~Hz}, 1 \mathrm{H})$, $5.18(\mathrm{~s}, 2 \mathrm{H}), 3.89(\mathrm{~s}, 3 \mathrm{H})$

8-Methoxy-3-propyl-1H,3H-pyrido[2,1-f]purine-2,4-dione (7) ${ }^{7,8}$ To a mixture of intermediate $1(1.1 \mathrm{~g}, 3.0 \mathrm{mmol}, 1.0$ equiv), $\mathrm{Pd}(\mathrm{OH})_{2} / \mathrm{C}(2.0 \mathrm{~g}, 14 \mathrm{mmol}, 1.0$ equiv), and ammonium formate $(0.20 \mathrm{~g}, 3.0 \mathrm{mmol}, 1.0$ equiv) was added $\mathrm{EtOH}(250 \mathrm{~mL})$. During the reaction, five portions of ammonium formate $(0.20 \mathrm{~g}, 3.0 \mathrm{mmol}, 1.0$ equiv) was added, after which completion of the reaction was observed by TLC $\left(5 \% \mathrm{MeOH}\right.$ in $\mathrm{CH}_{2} \mathrm{Cl}_{2}$ ). The reaction was filtered over Celite and the residue was extracted with hot DMF. Purification of the crude product was performed by column chromatography using $2-10 \% \mathrm{MeOH}$ in $\mathrm{CH}_{2} \mathrm{Cl}_{2}$ to obtain 5 as a white solid $(0.30 \mathrm{~g}, 1.2$ mmol, $40 \%) .{ }^{1} \mathrm{H}$ NMR (400 MHz, DMSO- $d_{6}$ ): $\delta 12.05$ (s, $\left.1 \mathrm{H}\right), 8.73$ $(\mathrm{d}, J=7.2 \mathrm{~Hz}, 1 \mathrm{H}), 7.12(\mathrm{~d}, J=2.0 \mathrm{~Hz}, 1 \mathrm{H}), 6.89(\mathrm{dd}, J=7.4,2.6 \mathrm{~Hz}$, $1 \mathrm{H}), 3.90(\mathrm{~s}, 3 \mathrm{H}), 3.85-3.78(\mathrm{~m}, 2 \mathrm{H}), 1.64-1.52(\mathrm{~m}, 2 \mathrm{H}), 0.88(\mathrm{t}, J$ $=7.4 \mathrm{~Hz}, 3 \mathrm{H})$

General Procedure for the Synthesis of Fluorosulfonylbenzoic Acids (9a,b). To a solution of chlorosulfonylbenzoic acid $(\mathbf{8 a}, \mathbf{b})$ $(2.2 \mathrm{~g}, 10 \mathrm{mmol}, 1.0$ equiv) in dioxane $(25 \mathrm{~mL})$ was added a solution of $\mathrm{HF} / \mathrm{KF}$ ( $15 \mathrm{~mL}, 2.0 \mathrm{M}, 3.0$ equiv). The mixture was stirred at room temperature. After $1 \mathrm{~h}$, the reaction mixture was diluted with EtOAc $(80 \mathrm{~mL})$. The organic phase was washed with $\mathrm{H}_{2} \mathrm{O}(50 \mathrm{~mL})$, dried over $\mathrm{MgSO}_{4}$, filtered, and concentrated in vacuo.

3-(Fluorosulfonyl)benzoic Acid (9a). White solid (1.9 g, $8.7 \mathrm{mmol}$, $87 \%) .{ }^{1} \mathrm{H}$ NMR $\left(400 \mathrm{MHz}, \mathrm{DMSO}-d_{6}\right): \delta 8.47-8.44(\mathrm{~m}, 2 \mathrm{H}), 8.4(\mathrm{~d}$, $J=8.0 \mathrm{~Hz}, 1 \mathrm{H}), 7.94(\mathrm{t}, J=7.6 \mathrm{~Hz}, 1 \mathrm{H})$.

4-(Fluorosulfonyl)benzoic Acid (9b). White solid $(2.0 \mathrm{~g}, 9.0 \mathrm{mmol}$, 90\%). ${ }^{1} \mathrm{H}$ NMR (400 MHz, DMSO- $\left.d_{6}\right): \delta 13.86(\mathrm{~s}, 1 \mathrm{H}), 8.28(\mathrm{~s}, 4 \mathrm{H})$

General Procedure for the Synthesis of Bromoalkyl (fluorosulfonyl)benzoates $(11 a-c$ and $12 a-c)$. A mixture of thionyl chloride $(8 \mathrm{~mL})$ and fluorosulfonylbenzoic acid $(9 \mathbf{a}, \mathbf{b})(1$ equiv) was refluxed at $75{ }^{\circ} \mathrm{C}$ for $3 \mathrm{~h}$. The solvent was removed under vacuum and the product was used in the next step without further analysis. Dry dioxane $(6 \mathrm{~mL})$ was added to the (fluorosulfonyl)benzoyl chloride $(\mathbf{1 0 a}, \mathbf{b})$. To this solution, the corresponding bromoalkylalcohol ( 0.85 equiv) was added and the mixture was refluxed overnight. After the completion of the reaction was observed by TLC $\left(\mathrm{CH}_{2} \mathrm{Cl}_{2}\right)$, the volatiles were removed in vacuo and the crude product was purified by column chromatography using $\mathrm{CH}_{2} \mathrm{Cl}_{2}$ as an eluent to afford the products.

2-Bromoethyl-4-(fluorosulfonyl)benzoate (11a). Colorless oil $(0.088 \mathrm{~g}, 0.28 \mathrm{mmol}, 23 \%){ }^{1} \mathrm{H}$ NMR (400 MHz, DMSO- $\left.d_{6}\right): \delta$ $8.31(\mathrm{~d}, J=8.2 \mathrm{~Hz}, 2 \mathrm{H}), 8.11(\mathrm{~d}, J=8.5 \mathrm{~Hz}, 2 \mathrm{H}), 4.69(\mathrm{t}, J=5.9 \mathrm{~Hz}$, $2 \mathrm{H}), 3.67(\mathrm{t}, J=5.9 \mathrm{~Hz}, 2 \mathrm{H})$.

3-Bromopropyl-4-(fluorosulfonyl)benzoate (11b). White solid $(2.0 \mathrm{~g}, 6.2 \mathrm{mmol}, 50 \%){ }^{1} \mathrm{H}$ NMR $\left(400 \mathrm{MHz}, \mathrm{CDCl}_{3}\right): \delta 8.27(\mathrm{~d}, J$ $=8.4 \mathrm{~Hz}, 2 \mathrm{H}), 8.09(\mathrm{~d}, J=8.4 \mathrm{~Hz}, 2 \mathrm{H}), 4.54(\mathrm{t}, J=6.0 \mathrm{~Hz}, 2 \mathrm{H}), 3.54$ $(\mathrm{d}, J=6.4 \mathrm{~Hz}, 2 \mathrm{H}), 2.35(\mathrm{~m}, 2 \mathrm{H})$.

4-Bromobutyl-4-(fluorosulfonyl)benzoate (11c). White solid $(0.30 \mathrm{~g}, 0.89 \mathrm{mmol}, 45 \%)$ compound was used without further purification.

2-Bromoethyl-3-(fluorosulfonyl)benzoate (12a). Colorless oil $(0.51 \mathrm{~g}, 1.7 \mathrm{mmol}, 55 \%){ }^{1} \mathrm{H}$ NMR $\left(400 \mathrm{MHz}, \mathrm{CDCl}_{3}\right): \delta 8.69(\mathrm{~s}$, $1 \mathrm{H}), 8.47(\mathrm{~d}, J=7.6 \mathrm{~Hz}, 1 \mathrm{H}), 8.25-8.20(\mathrm{~m}, 1 \mathrm{H}), 7.78(\mathrm{t}, J=8.0 \mathrm{~Hz}$, $1 \mathrm{H}), 4.71(\mathrm{t}, J=6.0 \mathrm{~Hz}, 2 \mathrm{H}), 3.68(\mathrm{t}, J=6.0 \mathrm{~Hz}, 2 \mathrm{H})$.

3-Bromopropyl-3-(fluorosulfonyl)benzoate (12b). Colorless oil $(0.12 \mathrm{~g}, 0.38 \mathrm{mmol}, 23 \%){ }^{1} \mathrm{H}$ NMR $\left(400 \mathrm{MHz}, \mathrm{CDCl}_{3}\right) \delta 8.65(\mathrm{t}, J=$ $1.6 \mathrm{~Hz}, 1 \mathrm{H}), 8.44(\mathrm{~d}, J=7.8 \mathrm{~Hz}, 1 \mathrm{H}), 8.21(\mathrm{~d}, J=8.0 \mathrm{~Hz}, 1 \mathrm{H}), 7.76$ $(\mathrm{t}, J=7.9 \mathrm{~Hz}, 1 \mathrm{H}), 4.55(\mathrm{t}, J=6.1 \mathrm{~Hz}, 1 \mathrm{H}), 3.55(\mathrm{t}, J=6.4 \mathrm{~Hz}, 1 \mathrm{H})$, $2.37(\mathrm{p}, J=6.3 \mathrm{~Hz}, 1 \mathrm{H})$.

4-Bromobutyl-3-(fluorosulfonyl)benzoate (12c). Colorless Oil (0.84 g, $2.5 \mathrm{mmol}, 83 \%$, ) ${ }^{1} \mathrm{H} \mathrm{NMR}\left(400 \mathrm{MHz}, \mathrm{CDCl}_{3}\right): \delta 8.65(\mathrm{~s}$, $1 \mathrm{H}), 8.45(\mathrm{~d}, J=8.0 \mathrm{~Hz}, 1 \mathrm{H}), 8.21(\mathrm{~d}, J=8.0 \mathrm{~Hz}, 1 \mathrm{H}), 7.78(\mathrm{t}, J=7.6$ $\mathrm{Hz}, 1 \mathrm{H}), 4.44(\mathrm{t}, J=6.0 \mathrm{~Hz}, 2 \mathrm{H}), 3.50(\mathrm{t}, J=6.4 \mathrm{~Hz}, 2 \mathrm{H}), 2.11-1.85$ (m, $4 \mathrm{H})$.

General Procedure for the Synthesis of $13 a-c$ and $14 a-c$. The synthesis of these compounds was adapted from the conditions previously described by Priego et al. ${ }^{6}$ The scaffolds 8-methoxy-3propyl-1H,3H-pyrido[2,1-f]purine-2,4-dione 7 (1.0 equiv) and $\mathrm{K}_{2} \mathrm{CO}_{3}$ (1.6 equiv) were suspended in anhydrous DMF. The mixture was added dropwise to a stirred solution of the corresponding bromoalkyl (fluorosulfonyl)benzoate (11a-c or $12 a-c)$ (1.0 equiv) in anhydrous DMF $(4 \mathrm{~mL})$. The reaction was stirred at $50{ }^{\circ} \mathrm{C}$ overnight. After the conversion was observed by TLC, an excess amount of $\mathrm{CH}_{2} \mathrm{Cl}_{2}$ was added. Then the mixture was washed with 1 $\mathrm{M} \mathrm{HCl}$ (aq.), water, and brine. The organic layer was dried over $\mathrm{MgSO}_{4}$, filtered, and concentrated in vacuo. The crude product was 
purified by column chromatography, followed by prep TLC to further purify the compound if necessary.

2-(8-Methoxy-2,4-dioxo-3-propyl-3,4-dihydropyrido[2,1-f]purine-1(2H)-yl)ethyl 4-(fluorosulfonyl)benzoate (13a). Prepared from 11a and purified by column chromatography $\left(1 \% \mathrm{CH}_{3} \mathrm{OH}\right.$ in $\left.\mathrm{CH}_{2} \mathrm{Cl}_{2}\right)$ to give the desired product as a white solid $(0.038 \mathrm{~g}, 0.07$ mmol, $52 \%) .{ }^{1} \mathrm{H}$ NMR $\left(400 \mathrm{MHz}, \mathrm{CDCl}_{3}\right): \delta 8.80(\mathrm{~d}, J=8.0 \mathrm{~Hz}$, $1 \mathrm{H}), 8.17(\mathrm{~d}, J=8.0 \mathrm{~Hz}, 2 \mathrm{H}), 7.98(\mathrm{~d}, J=8.4 \mathrm{~Hz}, 2 \mathrm{H}), 6.76-6.73$ $(\mathrm{m}, 2 \mathrm{H}), 4.78(\mathrm{t}, J=4.8 \mathrm{~Hz}, 2 \mathrm{H}), 4.64(\mathrm{t}, J=5.2 \mathrm{~Hz}, 2 \mathrm{H}), 4.00(\mathrm{t}, J=$ $7.6 \mathrm{~Hz}, 2 \mathrm{H}), 3.89(\mathrm{~s}, 3 \mathrm{H}), 1.73-1.62(\mathrm{~m}, 2 \mathrm{H}), 0.95(\mathrm{t}, J=7.2 \mathrm{~Hz}$, 3H). MS: [ESI $+\mathrm{H}]^{+}:$505.1. HPLC: $9.99 \mathrm{~min}$

3-(8-Methoxy-2,4-dioxo-3-propyl-3,4-dihydropyrido[2,1-f]purine-1(2H)-yl)propyl 4-(fluorosulfonyl)benzoate (13b). Prepared from $11 \mathbf{b}$ and purified by column chromatography $\left(1 \% \mathrm{CH}_{3} \mathrm{OH}\right.$ in $\left.\mathrm{CH}_{2} \mathrm{Cl}_{2}\right)$ to give the desired product as a white solid $(0.096 \mathrm{~g}, 0.19$ mmol, $76 \%) .{ }^{1} \mathrm{H}$ NMR $\left(400 \mathrm{MHz}, \mathrm{CDCl}_{3}\right): \delta 8.76(\mathrm{~d}, J=7.2 \mathrm{~Hz}$, $1 \mathrm{H}), 8.23(\mathrm{~d}, J=8.0 \mathrm{~Hz}, 2 \mathrm{H}), 8.06(\mathrm{~d}, J=8.4 \mathrm{~Hz}, 2 \mathrm{H}), 6.77(\mathrm{~d}, J=$ $2.4 \mathrm{~Hz}, 1 \mathrm{H}), 6.73(\mathrm{dd}, J=7.2,2.4 \mathrm{~Hz}, 1 \mathrm{H}), 4.50(\mathrm{t}, J=6.0 \mathrm{~Hz}, 2 \mathrm{H})$, $4.41(\mathrm{t}, J=6.8 \mathrm{~Hz}, 2 \mathrm{H}), 4.00(\mathrm{t}, J=7.2 \mathrm{~Hz}, 2 \mathrm{H}), 3.90(\mathrm{~s}, 3 \mathrm{H}), 2.38$ (pentet, $J=6.0 \mathrm{~Hz}, 2 \mathrm{H}), 1.71($ sextet $J=7.2 \mathrm{~Hz}, 2 \mathrm{H}), 0.99(\mathrm{t}, J=7.6$ $\mathrm{Hz}, 3 \mathrm{H})$. MS: $[\mathrm{ESI}+\mathrm{H}]^{+}:$519.1. HPLC: $10.18 \mathrm{~min}$

4-(8-Methoxy-2,4-dioxo-3-propyl-3,4-dihydropyrido[2,1-f]purine-1(2H)-yl)butyl 4-(fluorosulfonyl)benzoate (13c). Prepared from 11c and purified by column chromatography $\left(2 \% \mathrm{CH}_{3} \mathrm{OH}\right.$ in $\left.\mathrm{CH}_{2} \mathrm{Cl}_{2}\right)$ to give the desired product as a white solid $(0.010 \mathrm{~g}, 0.019$ mmol, 5.2\%) ${ }^{1} \mathrm{H}$ NMR (400 MHz, $\mathrm{CDCl}_{3}$ ): $\delta 8.83$ (dd, $J=7.6,0.8$ $\mathrm{Hz}, 1 \mathrm{H}), 8.27(\mathrm{~d}, J=8.0 \mathrm{~Hz}, 2 \mathrm{H}), 8.07(\mathrm{~d}, J=8.8 \mathrm{~Hz}, 2 \mathrm{H}), 6.93(\mathrm{~d}, J$ $=2.4 \mathrm{~Hz}, 1 \mathrm{H}), 6.76(\mathrm{dd}, J=7.6,2.4 \mathrm{~Hz}, 1 \mathrm{H}), 4.46(\mathrm{t}, J=6.4 \mathrm{~Hz}, 2 \mathrm{H})$, $4.28(\mathrm{t}, J=6.8 \mathrm{~Hz}, 2 \mathrm{H}), 4.02(\mathrm{t}, J=7.2 \mathrm{~Hz}, 2 \mathrm{H}), 3.93(\mathrm{~s}, 3 \mathrm{H}), 2.05-$ $1.90(\mathrm{~m}, 4 \mathrm{H}), 1.77-1.68(\mathrm{~m}, 2 \mathrm{H}), 0.99(\mathrm{t}, J=7.2 \mathrm{~Hz}, 3 \mathrm{H}) . \mathrm{MS}$ : [ESI $+\mathrm{H}]^{+}:$533.1. HPLC: $9.40 \mathrm{~min}$

2-(8-Methoxy-2,4-dioxo-3-propyl-3,4-dihydropyrido[2,1-f]purine-1(2H)-yl)ethyl 3-(fluorosulfonyl)benzoate (14a). Prepared from 12a and without purification to give the desired product as a white solid $(0.19 \mathrm{~g}, 0.36 \mathrm{mmol}, 57 \%) .{ }^{1} \mathrm{H}$ NMR (400 $\left.\mathrm{MHz}, \mathrm{CDCl}_{3}\right)$ : $\delta 8.80(\mathrm{~d}, J=7.2 \mathrm{~Hz}, 1 \mathrm{H}), 8.51(\mathrm{~s}, 1 \mathrm{H}), 8.36(\mathrm{~d}, J=7.6 \mathrm{~Hz}, 1 \mathrm{H})$, $8.14-8.09(\mathrm{~m}, 1 \mathrm{H}), 7.66(\mathrm{t}, J=7.8 \mathrm{~Hz}, 1 \mathrm{H}), 6.84(\mathrm{~d}, J=2.4 \mathrm{~Hz}, 1 \mathrm{H})$, $6.74(\mathrm{dd}, J=7.6,2.6 \mathrm{~Hz}, 1 \mathrm{H}), 4.78(\mathrm{t}, J=4.8 \mathrm{~Hz}, 2 \mathrm{H}), 4.65(\mathrm{t}, J=4.8$ $\mathrm{Hz}, 2 \mathrm{H}), 4.04-3.97(\mathrm{~m}, 2 \mathrm{H}), 3.90(\mathrm{~s}, 3 \mathrm{H}), 1.68$ (sextet, $J=7.6 \mathrm{~Hz}$, $2 \mathrm{H}), 0.96(\mathrm{t}, J=7.4 \mathrm{~Hz}, 3 \mathrm{H})$. MS: [ESI $+\mathrm{H}]^{+}:$505.1. HPLC: 8.47 $\min$

3-(8-Methoxy-2,4-dioxo-3-propyl-3,4-dihydropyrido[2,1-f]purine-1(2H)-yl)propyl 3-(fluorosulfonyl)benzoate (14b). Prepared from $12 b$ and purified by column chromatography $\left(1 \% \mathrm{CH}_{3} \mathrm{OH}\right.$ in $\left.\mathrm{CH}_{2} \mathrm{Cl}_{2}\right)$ to give the desired product as a white solid $(0.035 \mathrm{~g}, 0.068$ mmol, 34\%). ${ }^{1} \mathrm{H}$ NMR $\left(400 \mathrm{MHz}, \mathrm{CDCl}_{3}\right): \delta 8.74(\mathrm{~d}, J=7.6 \mathrm{~Hz}$, $1 \mathrm{H}), 8.65(\mathrm{~s}, 1 \mathrm{H}), 8.36(\mathrm{~d}, J=8.0 \mathrm{~Hz}, 1 \mathrm{H}), 8.18(\mathrm{~d}, J=8.0 \mathrm{~Hz}, 1 \mathrm{H})$, $7.73(\mathrm{t}, J=8.0 \mathrm{~Hz}, 1 \mathrm{H}), 6.86(\mathrm{~d}, J=2.0 \mathrm{~Hz}, 1 \mathrm{H}), 6.72(\mathrm{dd}, J=7.2$, $2.4 \mathrm{~Hz}, 1 \mathrm{H}), 4.51(\mathrm{t}, J=6.0 \mathrm{~Hz}, 2 \mathrm{H}), 4.41(\mathrm{t}, J=6.0 \mathrm{~Hz}, 2 \mathrm{H}), 3.99(\mathrm{t}$, $J=7.6 \mathrm{~Hz}, 2 \mathrm{H}), 3.91(\mathrm{~s}, 3 \mathrm{H}), 2.39$ (pentet, $J=6.0 \mathrm{~Hz}, 2 \mathrm{H}), 1.70$ (sextet, $J=7.6 \mathrm{~Hz}, 2 \mathrm{H}), 0.98(\mathrm{t}, J=7.6 \mathrm{~Hz}, 3 \mathrm{H}) . \mathrm{MS}$ : $[\mathrm{ESI}+\mathrm{H}]^{+}$: 519.1. HPLC: $8.84 \mathrm{~min}$

4-(8-Methoxy-2,4-dioxo-3-propyl-3,4-dihydropyrido[2,1-f]purine-1(2H)-yl)butyl 3-(fluorosulfonyl)benzoate (14c). Prepared from $12 \mathrm{c}$ and purified by column chromatography (first 30\% DCM in EtOAc). Further purification by another column (4:1 = methyl tertbutyl ether/petroleum ether) gives the desired product as a white solid (0.20 g, $0.37 \mathrm{mmol}, 38 \%) .{ }^{1} \mathrm{H}$ NMR $\left(400 \mathrm{MHz}, \mathrm{CDCl}_{3}\right): \delta 8.85$ $(\mathrm{d}, J=7.2 \mathrm{~Hz}, 1 \mathrm{H}), 8.67(\mathrm{~s}, 1 \mathrm{H}), 8.45(\mathrm{~d}, J=8.0 \mathrm{~Hz}, 1 \mathrm{H}), 8.21(\mathrm{~d}, J=$ $8.0 \mathrm{~Hz}, 1 \mathrm{H}), 7.75(\mathrm{t}, J=8.0 \mathrm{~Hz}, 1 \mathrm{H}), 6.97(\mathrm{~d}, J=2.4 \mathrm{~Hz}, 1 \mathrm{H}), 6.77$ $(\mathrm{dd}, J=7.2,2.4 \mathrm{~Hz}, 1 \mathrm{H}), 4.49(\mathrm{t}, J=6.4 \mathrm{~Hz}, 2 \mathrm{H}), 4.30(\mathrm{t}, J=7.2 \mathrm{~Hz}$, $2 \mathrm{H}), 4.08-4.01(\mathrm{~m}, 2 \mathrm{H}), 3.95(\mathrm{~s}, 3 \mathrm{H}), 2.10-2.00(\mathrm{~m}, 2 \mathrm{H}), 2.00-$ $1.89(\mathrm{~m}, 2 \mathrm{H}), 1.81-1.69(\mathrm{~m}, 2 \mathrm{H}), 1.01(\mathrm{t}, J=7.2 \mathrm{~Hz}, 3 \mathrm{H})$. MS: [ESI $+\mathrm{H}]^{+}$: 533.1. HPLC: $9.14 \mathrm{~min}$

General Procedure for the Synthesis of 1-(2-(1,3-Dioxoisoindolin-2-yl)alkyl)-8-methoxy-3-propyl-1H,3H-pyrido-[2,1f]purine-2,4-dione $(15 \mathrm{a}-\mathrm{c})$. To a mixture of the core (7) $(0.8$ mmol, 1 equiv), $\mathrm{N}$-(bromoalkyl)phthalimide ( $1.2 \mathrm{mmol}, 1.5$ equiv), and $\mathrm{K}_{2} \mathrm{CO}_{3}$ (1.2 mmol, 1.5 equiv) was added anhydrous DMF (8 $\mathrm{mL})$. The mixture was refluxed at $100{ }^{\circ} \mathrm{C}$. After completion of the reaction, monitored by TLC $\left(1 \% \mathrm{MeOH}\right.$ in $\left.\mathrm{CH}_{2} \mathrm{Cl}_{2}\right)$, the mixture was concentrated in vacuo and diluted with EtOAc $(30 \mathrm{~mL})$. The organic layer was washed with $\mathrm{H}_{2} \mathrm{O}(3 \times 30 \mathrm{~mL})$ and brine $(15 \mathrm{~mL})$, and dried over $\mathrm{MgSO}_{4}$. The solvent was evaporated under reduced pressure and the residue was purified by column chromatography using $1 \% \mathrm{MeOH}$ as an eluent to give $\mathbf{1 5 a}-\mathbf{c}$ as solids.

1-(2-(1,3-Dioxoisoindolin-2-yl)ethyl)-8-methoxy-3-propyl-1 H,3Hpyrido-[2,1-f]purine-2,4-dione (15a). Prepared from $\mathrm{N}$-(2bromoethyl)phthalimide and purified by column chromatography to give the desired product as a white solid $(0.20 \mathrm{~g}, 0.44 \mathrm{mmol}, 5 \%) .{ }^{1} \mathrm{H}$ $\operatorname{NMR}\left(\mathrm{CDCl}_{3}\right): \delta 8.77(\mathrm{~d}, J=6.8 \mathrm{~Hz}, 1 \mathrm{H}), 7.73(\mathrm{~s}, 2 \mathrm{H}), 7.64(\mathrm{~s}, 2 \mathrm{H})$, $6.69(\mathrm{~d}, J=14.0 \mathrm{~Hz}, 2 \mathrm{H}), 4.53(\mathrm{~s}, 2 \mathrm{H}), 4.17(\mathrm{~s}, 2 \mathrm{H}), 3.89(\mathrm{~d}, J=6.2$ $\mathrm{Hz}, 2 \mathrm{H}), 3.85(\mathrm{~s}, 3 \mathrm{H}), 1.58-1.45(\mathrm{~m}, 3 \mathrm{H}), 0.86(\mathrm{t}, J=7.2 \mathrm{~Hz}, 3 \mathrm{H})$

1-(2-(1,3-Dioxoisoindolin-2-yl)propyl)-8-methoxy-3-propyl$1 \mathrm{H}, 3 \mathrm{H}$-pyrido-[2,1-f]purine-2,4-dione (15b). Prepared from $\mathrm{N}$-(3bromoethyl)phthalimide and purified by column chromatography to give the desired product as a yellow solid $(0.31 \mathrm{~g}, 0.66 \mathrm{mmol}, 66 \%)$. ${ }^{1} \mathrm{H}$ NMR $\left(400 \mathrm{MHz}, \mathrm{CDCl}_{3}\right): \delta 8.81-8.75(\mathrm{~m}, 1 \mathrm{H}), 7.86-7.76(\mathrm{~m}$, $2 \mathrm{H}), 7.73-7.61(\mathrm{~m}, 2 \mathrm{H}), 6.80(\mathrm{~s}, 1 \mathrm{H}), 6.72(\mathrm{dd}, J=7.2,2.4 \mathrm{~Hz}, 1 \mathrm{H})$, $4.29(\mathrm{t}, J=6.8 \mathrm{~Hz}, 2 \mathrm{H}), 4.04-3.93(\mathrm{~m}, 2 \mathrm{H}), 3.90(\mathrm{~s}, 3 \mathrm{H}), 3.86-3.78$ $(\mathrm{m}, 2 \mathrm{H}), 2.35-2.20(\mathrm{~m}, 2 \mathrm{H}), 1.78-1.60(\mathrm{~m}, 2 \mathrm{H}), 1.06-0.87(\mathrm{~m}$, $3 \mathrm{H})$.

1-(2-(1,3-Dioxoisoindolin-2-yl)butyl)-8-methoxy-3-propyl$1 \mathrm{H}, 3 \mathrm{H}$-pyrido-[2,1-f]purine-2,4-dione (15c). Prepared from N-(4bromoethyl)phthalimide and purified by column chromatography to give the desired product as a white solid $(0.37 \mathrm{~g}, 0.76 \mathrm{mmol}, 96 \%) .{ }^{1} \mathrm{H}$ NMR $\left(400 \mathrm{MHz}, \mathrm{CDCl}_{3}\right): \delta 8.82(\mathrm{~d}, J=7.2 \mathrm{~Hz}, 1 \mathrm{H}), 7.82(\mathrm{dd}, J=$ $5.2,2.8 \mathrm{~Hz}, 2 \mathrm{H}), 7.70(\mathrm{dd}, J=5.2,2.8 \mathrm{~Hz}, 2 \mathrm{H}), 6.93(\mathrm{~d}, J=2.4 \mathrm{~Hz}$, $1 \mathrm{H}), 6.74(\mathrm{dd}, J=7.2,2.4 \mathrm{~Hz}, 1 \mathrm{H}), 4.22(\mathrm{~d}, J=7.2 \mathrm{~Hz}, 2 \mathrm{H}), 4.04-$ $3.96(\mathrm{~m}, 2 \mathrm{H}), 3.92(\mathrm{~s}, 3 \mathrm{H}), 3.75(\mathrm{~d}, J=7.2 \mathrm{~Hz}, 2 \mathrm{H}), 1.95-1.85(\mathrm{~m}$, $2 \mathrm{H}), 1.85-1.77(\mathrm{~m}, 2 \mathrm{H}), 1.74-1.65(\mathrm{~m}, 3 \mathrm{H}), 0.97(\mathrm{~d}, J=7.6 \mathrm{~Hz}$, $3 \mathrm{H})$.

General Procedure for the Synthesis of 1-(2-Aminoalkyl)-8methoxy-3-propyl-1H,3H-pyrido-[2,1-f]purine-2,4-dione $(16 \mathrm{a}-\mathrm{c})$. To a stirred suspension of $15 \mathrm{a}-\mathrm{c}(0.66 \mathrm{mmol}, 1$ equiv) in $\mathrm{MeOH}(8 \mathrm{~mL})$ was added excess hydrazine monohydrate $(4.8 \mathrm{~mL}, 99$ $\mathrm{mmol}$ ). The mixture was stirred for $2-4 \mathrm{~h}$ at reflux. After conversion of the starting material, the mixture was cooled to room temperature. The solvents were removed under vacuum and the residue was dissolved in $2 \mathrm{M} \mathrm{NaOH}$ (aq.) $(25 \mathrm{~mL})$. This aqueous phase was extracted three times with $\mathrm{CH}_{2} \mathrm{Cl}_{2}(25 \mathrm{~mL})$. The organic layers were combined, dried over $\mathrm{MgSO}_{4}$, and concentrated in vacuo to obtain $16 \mathrm{a}-\mathrm{c}$.

1-(2-Aminoethyl)-8-methoxy-3-propyl-1H,3H-pyrido-[2,1-f]purine-2,4-dione (16a). Prepared from 15a and purified by column chromatography to give the desired product as a white solid $(0.13 \mathrm{~g}$, $0.39 \mathrm{mmol}, 90 \%) .{ }^{1} \mathrm{H}$ NMR $\left(400 \mathrm{MHz}, \mathrm{CDCl}_{3}\right): \delta 8.84(\mathrm{~d}, J=7.6$ $\mathrm{Hz}, 1 \mathrm{H}), 6.95(\mathrm{~d}, J=2.4 \mathrm{~Hz}, 1 \mathrm{H}), 6.75(\mathrm{dd}, J=7.2,2.4 \mathrm{~Hz}, 1 \mathrm{H}), 4.27$ $(\mathrm{t}, J=6.4 \mathrm{~Hz}, 2 \mathrm{H}), 4.05-3.99(\mathrm{~m}, 2 \mathrm{H}), 3.93(\mathrm{~s}, 3 \mathrm{H}), 3.15(\mathrm{t}, J=6.4$ $\mathrm{Hz}, 2 \mathrm{H}), 1.78-1.67(\mathrm{~m}, 2 \mathrm{H}), 0.99(\mathrm{~d}, J=7.6 \mathrm{~Hz}, 3 \mathrm{H})$.

1-(3-Aminopropyl)-8-methoxy-3-propyl-1H,3H-pyrido-[2,1-f]purine-2,4-dione (16b). Prepared from 15b and purified by column chromatography to give the desired product as a white solid $(0.25 \mathrm{~g}$, $0.75 \mathrm{mmol}, 97 \%) .{ }^{1} \mathrm{H}$ NMR $\left(400 \mathrm{MHz}, \mathrm{CDCl}_{3}\right): \delta 8.82(\mathrm{~d}, J=7.2$ $\mathrm{Hz}, 1 \mathrm{H}), 6.95(\mathrm{~d}, J=2.4 \mathrm{~Hz}, 1 \mathrm{H}), 6.75(\mathrm{dd}, J=7.6,2.4 \mathrm{~Hz}, 1 \mathrm{H}), 4.29$ $(\mathrm{t}, J=6.8 \mathrm{~Hz}, 2 \mathrm{H}), 4.07-3.98(\mathrm{~m}, 2 \mathrm{H}), 3.93(\mathrm{~s}, 3 \mathrm{H}), 2.75(\mathrm{t}, J=6.6$ $\mathrm{Hz}, 2 \mathrm{H}), 1.98(\mathrm{p}, J=6.6 \mathrm{~Hz}, 2 \mathrm{H}), 1.78-1.65(\mathrm{~m}, 2 \mathrm{H}), 0.99(\mathrm{t}, J=7.4$ $\mathrm{Hz}, 3 \mathrm{H})$.

1-(4-Aminobutyl)-8-methoxy-3-propyl-1H,3H-pyrido-[2,1-f]purine-2,4-dione $(16 \mathrm{c})$. Prepared from $15 \mathrm{c}$ and purified by column chromatography to give the desired product as a white solid $(0.23 \mathrm{~g}$, $0.66 \mathrm{mmol}, 86 \%) .{ }^{1} \mathrm{H}$ NMR $\left(400 \mathrm{MHz}, \mathrm{CDCl}_{3}\right): \delta 8.84(\mathrm{~d}, J=7.6$ $\mathrm{Hz}, 1 \mathrm{H}), 6.97(\mathrm{~d}, J=2.4 \mathrm{~Hz}, 1 \mathrm{H}), 6.75(\mathrm{dd}, J=7.2,2.4 \mathrm{~Hz}, 1 \mathrm{H}), 4.20$ $(\mathrm{t}, J=7.2 \mathrm{~Hz}, 2 \mathrm{H}), 4.06-3.98(\mathrm{~m}, 2 \mathrm{H}), 3.92(\mathrm{~s}, 3 \mathrm{H}), 2.77(\mathrm{~d}, J=6.8$ $\mathrm{Hz}, 2 \mathrm{H}), 1.92-1.82(\mathrm{~m}, 2 \mathrm{H}), 1.78-1.66(\mathrm{~m}, 2 \mathrm{H}), 1.63-1.53(\mathrm{~m}$, $2 \mathrm{H}), 0.99(\mathrm{t}, J=7.2 \mathrm{~Hz}, 3 \mathrm{H})$.

4-((2-(8-Methoxy-2,4-dioxo-3-propyl-3,4-dihydropyrido[2,1-f]purin-1(2H)-yl)ethyl)carbamoyl)benzenesulfonyl Fluoride (17a). EDC ( $0.12 \mathrm{~g}, 0.60 \mathrm{mmol}, 1.2$ equiv) was dissolved in $\mathrm{CHCl}_{3}$ (4 $\mathrm{mL})$. To this stirring solution was added the acid $(9 \mathrm{a})(0.11 \mathrm{~g}, 0.55$ mmol, 1.1 equiv). The amine (16a) $(0.16 \mathrm{~g}, 0.50 \mathrm{mmol}, 1.0$ equiv) was suspended in $\mathrm{CHCl}_{3}(6 \mathrm{~mL})$ and then was added dropwise via an 
automatic syringe at a rate of $0.2 \mathrm{~mL} \mathrm{~min}^{-1}$. The reaction was stirred for $1.5 \mathrm{~h}$ at room temperature and monitored by TLC $\left(\mathrm{CH}_{2} \mathrm{Cl}_{2} /\right.$ acetone $=3: 2$ ). After completion, the solvent was removed under vacuum and the residue was redissolved in $\mathrm{CHCl}_{3}(40 \mathrm{~mL})$. The organic layer was washed with $1 \mathrm{M} \mathrm{HCl}(40 \mathrm{~mL})$ and $\mathrm{H}_{2} \mathrm{O}(2 \times 40$ $\mathrm{mL}$ ), dried over $\mathrm{MgSO}_{4}$, and concentrated in vacuo to obtain $17 \mathbf{a}$ as a white solid (0.20 g, $0.39 \mathrm{mmol}, 78 \%) .{ }^{1} \mathrm{H} \mathrm{NMR}\left(400 \mathrm{MHz}, \mathrm{CDCl}_{3}\right)$ : $\delta 8.83(\mathrm{~d}, J=7.2 \mathrm{~Hz}, 1 \mathrm{H}), 8.07-8.00(\mathrm{~m}, 5 \mathrm{H}), 6.91(\mathrm{~d}, J=2.4 \mathrm{~Hz}$, $1 \mathrm{H}), 6.80(\mathrm{dd}, J=7.2,2.0 \mathrm{~Hz}, 1 \mathrm{H}), 4.62-4.55(\mathrm{~m}, 2 \mathrm{H}), 4.03(\mathrm{t}, J=$ $7.6 \mathrm{~Hz}, 2 \mathrm{H}), 3.95(\mathrm{~s}, 3 \mathrm{H}), 3.94-3.89(\mathrm{~m}, 2 \mathrm{H}), 1.68$ (sextet, $J=7.6$ $\mathrm{Hz}, 2 \mathrm{H}), 0.97(\mathrm{t}, J=7.2 \mathrm{~Hz}, 3 \mathrm{H})$. MS: [ESI $+\mathrm{H}]^{+}:$504.1. HPLC: $7.93 \mathrm{~min}$.

4-((3(8-Methoxy-2,4-dioxo-3-propyl-3,4-dihydropyrido[2,1-f]purin-1(2H)yl)propyl)carbamoyl)benzenesulfonyl Fluoride (17b). A suspension of EDC $(0.22 \mathrm{~g}, 0.80 \mathrm{mmol}, 1.5$ equiv) and $9 \mathrm{a}(0.16 \mathrm{~g}$, $0.80 \mathrm{mmol} 1.05$ equiv) was dissolved in $\mathrm{CH}_{2} \mathrm{Cl}_{2}(4 \mathrm{~mL})$. To this stirring solution amine was added $(\mathbf{1 6 b})(0.25 \mathrm{~g}, 0.76 \mathrm{mmol}, 1.0$ equiv) at room temperature. The reaction was stirred for $2 \mathrm{~h}$ and monitored by TLC $\left(3 \% \mathrm{MeOH}\right.$ in $\left.\mathrm{CH}_{2} \mathrm{Cl}_{2}\right)$. After completion, the solvent was removed in vacuo and the residue was dissolved in $\mathrm{CHCl}_{3}$ $(40 \mathrm{~mL})$. The organic layer was washed with $1 \mathrm{M} \mathrm{HCl}(40 \mathrm{~mL})$ and twice with $\mathrm{H}_{2} \mathrm{O}(2 \times 40 \mathrm{~mL})$, dried over $\mathrm{MgSO}_{4}$, and concentrated in vacuo. The product was purified by column chromatography using $2 \%$ $\mathrm{MeOH}$ in $\mathrm{CH}_{2} \mathrm{Cl}_{2}$ to afford the title compound as a white solid $(0.26$ g, $0.50 \mathrm{mmol}, 66 \%) .{ }^{1} \mathrm{H}$ NMR (400 MHz, $\mathrm{CDCl}_{3}$ ) $\delta: 8.86$ (d, $J=7.2$ $\mathrm{Hz}, 1 \mathrm{H}), 8.38(\mathrm{t}, J=5.6 \mathrm{~Hz}, 1 \mathrm{H}), 8.25(\mathrm{~d}, J=8.4 \mathrm{~Hz}, 2 \mathrm{H}), 8.16(\mathrm{~d}, J$ $=8.4 \mathrm{~Hz}, 2 \mathrm{H}), 6.85(\mathrm{~d}, J=2.4 \mathrm{~Hz}, 1 \mathrm{H}), 6.81(\mathrm{dd}, J=7.2,2.4 \mathrm{~Hz}$, $1 \mathrm{H}), 4.35(\mathrm{t}, J=6.0 \mathrm{~Hz}, 2 \mathrm{H}), 4.05(\mathrm{t}, J=7.6 \mathrm{~Hz}, 2 \mathrm{H}), 3.92(\mathrm{~s}, 3 \mathrm{H})$, $3.47(\mathrm{q}, J=6.4 \mathrm{~Hz}, 2 \mathrm{H}), 2.19-2.13(\mathrm{~m}, 2 \mathrm{H}), 1.73$ (sextet, $J=7.6 \mathrm{~Hz}$, $2 \mathrm{H}), 1.00(\mathrm{t}, J=7.6 \mathrm{~Hz}, 3 \mathrm{H}) .{ }^{13} \mathrm{C}$ NMR $\left(600 \mathrm{MHz}, \mathrm{DMSO}-d_{6}, 348\right.$ K) $\delta 164.0,160.9,153.4,150.6,150.5,149.1,141.3,133.3(\mathrm{~d}, J=96$ $\mathrm{Hz}), 128.5,127.9,127.3,107.0,99.8,95.4,55.7,41.5,40.6,36.8,27.1$ 20.5, 10.6. MS: $[\mathrm{ESI}+\mathrm{H}]^{+}:$518.1. HRMS-ESI ${ }^{+}:[\mathrm{M}+\mathrm{H}]^{+}$calcd: 518.1510 found: $518.1540, \mathrm{C}_{23} \mathrm{H}_{25} \mathrm{O}_{6} \mathrm{~N}_{5} \mathrm{FS}$. HPLC: $8.27 \mathrm{~min}$.

4-((4-(8-Methoxy-2,4-dioxo-3-propyl-3,4-dihydropyrido[2,1-f]purin-1(2H)-yl)butyl)carbamoyl)benzenesulfonyl Fluoride (17c). Acid 9a (0.11 g, $0.53 \mathrm{mmol}, 1.5$ equiv) was dissolved in an excess of thionyl chloride $(20 \mathrm{~mL})$ at $75{ }^{\circ} \mathrm{C}$ under nitrogen for $3 \mathrm{~h}$. After removal of solvent and other volatiles under vacuum, 10a was obtained as a colorless oil. Subsequently, amine $16 \mathrm{c}(0.12 \mathrm{~g}, 0.35$ mmol, 1.0 equiv), $\mathrm{K}_{2} \mathrm{CO}_{3}$ ( $0.073 \mathrm{~g}, 0.53 \mathrm{mmol}, 1.5$ equiv), and dry DMF were added and the reaction as stirred at $40{ }^{\circ} \mathrm{C}$ overnight. After completion of the reaction, $1 \mathrm{M} \mathrm{HCl}(200 \mathrm{~mL})$ was added and extracted with $\mathrm{CH}_{2} \mathrm{Cl}_{2}(150 \mathrm{~mL})$. The organic layer was washed with water $(100 \mathrm{~mL})$ and brine $(100 \mathrm{~mL})$. The organic layer was dried, filtered, and concentrated in vacuo. The residue was purified by column chromatography using $\mathrm{CH}_{2} \mathrm{Cl}_{2}$ with $1 \%$ methanol as the eluent to give $17 \mathrm{c}$ as a white solid $(5.0 \mathrm{mg}, 0.0094 \mathrm{mmol}, 4 \%) .{ }^{1} \mathrm{H}$ NMR (400 MHz, $\mathrm{CDCl}_{3}$ ): $\delta 8.87(\mathrm{~d}, J=7.6 \mathrm{~Hz}, 1 \mathrm{H}), 8.17(\mathrm{~d}, J=8.4$ $\mathrm{Hz}, 2 \mathrm{H}), 8.09(\mathrm{~d}, J=8.4 \mathrm{~Hz}, 2 \mathrm{H}), 7.54($ brs, $1 \mathrm{H}), 6.85(\mathrm{~s}, 1 \mathrm{H}), 6.80$ $(\mathrm{dd}, J=7.2,2.4 \mathrm{~Hz}, 1 \mathrm{H}), 4.29(\mathrm{t}, J=7.6 \mathrm{~Hz}, 2 \mathrm{H}), 4.06(\mathrm{t}, J=7.6 \mathrm{~Hz}$, $2 \mathrm{H}), 3.92(\mathrm{~s}, 3 \mathrm{H}), 3.68(\mathrm{q}, J=6.0 \mathrm{~Hz}, 2 \mathrm{H}), 2.01$ (pent, $J=6.8 \mathrm{~Hz}$, $2 \mathrm{H}), 1.84-1.70(\mathrm{~m}, 4 \mathrm{H}), 1.02(\mathrm{t}, J=7.6 \mathrm{~Hz}, 3 \mathrm{H})$. MS: [ESI $+\mathrm{H}]^{+}$: 532.3. HPLC: $8.28 \mathrm{~min}$.

3-((2-(8-Methoxy-2,4-dioxo-3-propyl-3,4-dihydropyrido[2,1-f]purin-1(2H)-yl)ethyl)carbamoyl)benzenesulfonyl Fluoride (18a). EDC ( $0.12 \mathrm{~g}, 0.60 \mathrm{mmol}, 1.2$ equiv) was dissolved in $\mathrm{CHCl}_{3}$ (4 $\mathrm{mL})$. To this stirring solution was added acid $9 \mathrm{~b}(0.11 \mathrm{~g}, 0.55 \mathrm{mmol}$, 1.1 equiv). Amine $16 \mathrm{a}(0.16 \mathrm{~g}, 0.50 \mathrm{mmol}, 1.0$ equiv) was suspended in $\mathrm{CHCl}_{3}(6 \mathrm{~mL})$ and then was added dropwise via an automatic syringe at a rate of $0.2 \mathrm{~mL} \mathrm{~min}^{-1}$. The reaction was stirred for $3 \mathrm{~h}$ at room temperature and monitored by TLC $\left(\mathrm{CH}_{2} \mathrm{Cl}_{2} /\right.$ acetone $\left.=3: 2\right)$. After completion, the solvent was removed in vacuo and the residue was resolubilized in $\mathrm{CHCl}_{3}(40 \mathrm{~mL})$. The organic layer was washed with $1 \mathrm{M} \mathrm{HCl}(40 \mathrm{~mL})$ and twice with $\mathrm{H}_{2} \mathrm{O}(2 \times 40 \mathrm{~mL})$, dried over $\mathrm{MgSO}_{4}$, and concentrated in vacuo to give 18a as a white solid (0.17 g, $0.35 \mathrm{mmol}, 70 \%) .{ }^{1} \mathrm{H}$ NMR (400 MHz, $\left.\mathrm{CDCl}_{3}\right): \delta 8.81$ (d, $J=7.6$ $\mathrm{Hz}, 1 \mathrm{H}), 8.37(\mathrm{~s}, 1 \mathrm{H}), 8.29(\mathrm{~d}, J=8.0 \mathrm{~Hz}, 1 \mathrm{H}), 8.11(\mathrm{~d}, J=7.6 \mathrm{~Hz}$, $1 \mathrm{H}), 8.04(\mathrm{br} \mathrm{s}, 1 \mathrm{H}), 7.71(\mathrm{t}, J=8.0 \mathrm{~Hz}, 1 \mathrm{H}), 7.02(\mathrm{~d}, J=2.4 \mathrm{~Hz}$, $1 \mathrm{H}), 6.77(\mathrm{dd}, J=7.6,2.4 \mathrm{~Hz}, 1 \mathrm{H}), 4.61-4.54(\mathrm{~m}, 2 \mathrm{H}), 4.03(\mathrm{t}, J=$
$7.6 \mathrm{~Hz}, 2 \mathrm{H}), 3.96(\mathrm{~s}, 3 \mathrm{H}), 3.94-3.89(\mathrm{~m}, 2 \mathrm{H}), 1.76-1.63(\mathrm{~m}, 2 \mathrm{H})$, $0.97(\mathrm{t}, J=7.6 \mathrm{~Hz}, 3 \mathrm{H})$. MS: [ESI $+\mathrm{H}]^{+}: 504.1$. HPLC: $7.67 \mathrm{~min}$.

3-((3-(8-Methoxy-2,4-dioxo-3-propyl-3,4-dihydropyrido[2,1-f]purin-1(2H)-yl)propyl)carbamoyl) benzenesulfonyl Fluoride (18b). Acid 9b $(0.42 \mathrm{~g}, 2.0 \mathrm{mmol}, 3.0$ equiv) was dissolved in thionyl chloride $(20 \mathrm{~mL})$ and stirred for $3 \mathrm{~h}$ at $75{ }^{\circ} \mathrm{C}$. The thionyl chloride was evaporated and the residue was co-evaporated twice with toluene. Then, amine $14 \mathrm{~b}\left(0.23 \mathrm{mg}, 0.7 \mathrm{mmol}, 1.00\right.$ equiv), $\mathrm{K}_{2} \mathrm{CO}_{3}(0.073 \mathrm{~g}$, $0.53 \mathrm{mmol}, 1.5$ equiv), and dry DMF were added and the reaction was stirred at $40{ }^{\circ} \mathrm{C}$ overnight. $1 \mathrm{M} \mathrm{HCl}(200 \mathrm{~mL})$ was added and extracted with $\mathrm{CH}_{2} \mathrm{Cl}_{2}(150 \mathrm{~mL})$. The organic layer was washed with water $(100 \mathrm{~mL})$ and brine $(100 \mathrm{~mL})$. The organic layer was dried, filtered, and concentrated in vacuo. The residue was purified by column chromatography using $\mathrm{CH}_{2} \mathrm{Cl}_{2}$ with $1 \%$ methanol as the eluent to give $18 \mathrm{~b}$ as a white solid $(0.0050 \mathrm{~g}, 0.01 \mathrm{mmol}, 2.7 \%) .{ }^{1} \mathrm{H}$ $\operatorname{NMR}\left(400 \mathrm{MHz}, \mathrm{CDCl}_{3}\right) \delta: 8.88(\mathrm{~d}, J=7.2 \mathrm{~Hz}, 1 \mathrm{H}), 8.68(\mathrm{~s}, 1 \mathrm{H})$, $8.55-8.50(\mathrm{~m}, 2 \mathrm{H}), 8.20(\mathrm{~d}, J=8.0 \mathrm{~Hz}, 1 \mathrm{H}), 7.82(\mathrm{t}, J=8 \mathrm{~Hz}, 2 \mathrm{H})$, $7.00(\mathrm{~d}, J=2.4 \mathrm{~Hz}, 1 \mathrm{H}), 6.80(\mathrm{dd}, J=7.2,2.4 \mathrm{~Hz}, 1 \mathrm{H}), 4.33(\mathrm{t}, J=$ $6.0 \mathrm{~Hz}, 2 \mathrm{H}), 4.05(\mathrm{t}, J=7.6 \mathrm{~Hz}, 2 \mathrm{H}), 3.94(\mathrm{~s}, 3 \mathrm{H}), 3.47(\mathrm{q}, \mathrm{J}=6.0$ $\mathrm{Hz}, 2 \mathrm{H}), 2.17-2.12(\mathrm{~m}, 2 \mathrm{H}), 1.74$ (sextet, $J=7.6 \mathrm{~Hz}, 2 \mathrm{H}), 1.00(\mathrm{t}, J$ $=7.6 \mathrm{~Hz}, 3 \mathrm{H})$. MS: ESI $[\mathrm{M}+\mathrm{H}]^{+}: 518.1$ HPLC: $8.28 \mathrm{~min}$.

3-((4-(8-Methoxy-2,4-dioxo-3-propyl-3,4-dihydropyrido[2,1-f]purin-1(2H)-yl)butyl)carbamoyl)benzenesulfonyl Fluoride (18c). EDC ( $0.13 \mathrm{~g}, 0.69 \mathrm{mmol}, 1.2$ equiv) was dissolved in $\mathrm{CH}_{2} \mathrm{Cl}_{2}$ (3 $\mathrm{mL})$. Acid $9 \mathrm{~b}(0.13 \mathrm{~g}, 0.63 \mathrm{mmol}, 1.1$ equiv) was added to this solution and the mixture was stirred. Amine $16 \mathrm{c}(0.20 \mathrm{~g}, 0.57 \mathrm{mmol}, 1$ equiv) was dissolved in $\mathrm{CHCl}_{3}(8 \mathrm{~mL})$ and added dropwise via an automatic syringe at a rate of $0.2 \mathrm{~mL} \mathrm{~min}{ }^{-1}$ to the stirring solution. After $3 \mathrm{~h}$ at room temperature, the reaction was completed and the mixture was concentrated in vacuo. The residue was dissolved in $\mathrm{CH}_{2} \mathrm{Cl}_{2}(40 \mathrm{~mL})$ and washed with $1 \mathrm{M} \mathrm{HCl}(40 \mathrm{~mL})$ and twice with $\mathrm{H}_{2} \mathrm{O}(2 \times 40 \mathrm{~mL})$. The organic layer was dried over $\mathrm{MgSO}_{4}$ and concentrated in vacuo. Purification by column chromatography $\left(\mathrm{CH}_{2} \mathrm{Cl}_{2} /\right.$ acetone $\left.=3: 2\right)$ gave $18 \mathrm{c}$ as a white solid $(0.14 \mathrm{~g}, 0.26$ mmol, 47\%). ${ }^{1} \mathrm{H}$ NMR (400 MHz, $\left.\mathrm{CDCl}_{3}\right): \delta 8.84(\mathrm{~d}, J=7.2 \mathrm{~Hz}$, $1 \mathrm{H}), 8.54(\mathrm{~s}, 1 \mathrm{H}), 8.36(\mathrm{~d}, J=7.6 \mathrm{~Hz}, 1 \mathrm{H}), 8.12(\mathrm{~d}, J=7.6 \mathrm{~Hz}, 1 \mathrm{H})$, $7.72(\mathrm{t}, J=7.6 \mathrm{~Hz}, 1 \mathrm{H}), 7.62(\mathrm{br} \mathrm{s}, 1 \mathrm{H}), 6.84(\mathrm{~s}, 1 \mathrm{H}), 6.80-6.70(\mathrm{~m}$, $1 \mathrm{H}), 4.27(\mathrm{t}, J=7.2 \mathrm{~Hz}, 2 \mathrm{H}), 4.04(\mathrm{t}, J=8.0 \mathrm{~Hz}, 2 \mathrm{H}), 3.89(\mathrm{~s}, 3 \mathrm{H})$, $3.74-3.60(\mathrm{~m}, 2 \mathrm{H}), 2.07-1.92(\mathrm{~m}, 2 \mathrm{H}), 1.85-1.64(\mathrm{~m}, 4 \mathrm{H}), 0.98(\mathrm{t}$, $J=7.2 \mathrm{~Hz}, 3 \mathrm{H})$. MS: [ESI $+\mathrm{H}]^{+}$: 532.3. HPLC: $8.21 \mathrm{~min}$.

$\mathrm{N}$-(3-(8-Methoxy-2,4-dioxo-3-propyl-3,4-dihydropyrido[2,1-f]purin-1(2H)-yl)propyl)-4-(methylsulfonyl)benzamide (19). To a solution of EDC $\left(0.061 \mathrm{~g}, 0.32 \mathrm{mmol}, 1.2\right.$ equiv) in $\mathrm{CHCl}_{3}(5 \mathrm{~mL})$ was added 4-(methylsulfonyl)benzoic acid $(0.060 \mathrm{~g}, 0.30 \mathrm{mmol}, 1.1$ equiv). Amine 16b (0.090 g, $0.27 \mathrm{mmol}, 1$ equiv) was taken up in $\mathrm{CHCl}_{3}(5 \mathrm{~mL})$ and was subsequently added dropwise via an automatic syringe at a rate of $0.15 \mathrm{~mL} \mathrm{~min}^{-1}$. The reaction was stirred at room temperature and monitored by TLC $\left(4 \% \mathrm{MeOH}\right.$ in $\left.\mathrm{CH}_{2} \mathrm{Cl}_{2}\right)$. After $3 \mathrm{~h}$, the reaction was completed and $\mathrm{CHCl}_{3}(50 \mathrm{~mL})$ was added. The organic layer was washed with $1 \mathrm{M} \mathrm{HCl}(60 \mathrm{~mL}), \mathrm{H}_{2} \mathrm{O}(60 \mathrm{~mL})$, and brine $(60 \mathrm{~mL})$, dried over $\mathrm{MgSO}_{4}$, and concentrated under vacuum. The product was purified by column chromatography using $2 \% \mathrm{MeOH}$ in $\mathrm{CH}_{2} \mathrm{Cl}_{2}$ to afford the title compound $(0.075 \mathrm{~g}, 0.14$ mmol, 54\%). ${ }^{1} \mathrm{H}$ NMR (400 MHz, $\left.\mathrm{CDCl}_{3}\right): \delta 8.86(\mathrm{~d}, J=7.2 \mathrm{~Hz}$, $1 \mathrm{H}), 8.36(\mathrm{t}, J=5.6 \mathrm{~Hz}, 1 \mathrm{H}), 8.19(\mathrm{~d}, J=8.4 \mathrm{~Hz}, 2 \mathrm{H}), 8.09(\mathrm{~d}, J=8.4$ $\mathrm{Hz}, 2 \mathrm{H}), 6.90-6.71(\mathrm{~m}, 2 \mathrm{H}), 4.45-4.28(\mathrm{~m}, 2 \mathrm{H}), 4.13-3.99(\mathrm{~m}$, $2 \mathrm{H}), 3.91(\mathrm{~s}, 3 \mathrm{H}), 3.55-3.41(\mathrm{~m}, 2 \mathrm{H}), 3.11(\mathrm{~s}, 3 \mathrm{H}), 2.27-2.09(\mathrm{~m}$, $2 \mathrm{H}), 1.83-1.61(\mathrm{~m}, 2 \mathrm{H}), 1.00(\mathrm{t}, J=7.4 \mathrm{~Hz}, 3 \mathrm{H}) .{ }^{13} \mathrm{C}$ NMR $(600$ $\left.\mathrm{MHz}, \mathrm{DMSO}-d_{6}, 318 \mathrm{~K}\right): \delta 164.7,161.1,153.5,150.7,150.6,149.3$, $142.8,138.9,127.9,127.5,126.7,107.4,99.9,95.4,56.0,43.2,41.6$, 40.8, 36.8, 27.4, 20.7, 10.9. MS: [ESI + H] $]^{+}:$514.2. HRMS-ESI ${ }^{+}:[\mathrm{M}$ $+\mathrm{H}]^{+}$calcd: 518.1760 found: 518.1791, $\mathrm{C}_{24} \mathrm{H}_{28} \mathrm{O}_{6} \mathrm{~N}_{5} \mathrm{~S}$. HPLC: 6.89 min.

Computational Studies. All calculations were performed using the Schrodinger Suite. ${ }^{31}$ Since compound $\mathbf{1 7 b}$ shares high similarity with the ligands on which we previously published, the same homology model based on the high-resolution antagonist-bound crystal structure of the adenosine $\mathrm{A}_{2 \mathrm{~A}}$ receptor (PDB: $4 \mathrm{EIY}^{27}$ ) was used for the docking studies performed here. Based on these proposed 
docking poses, we used induced fit docking ${ }^{32}$ with core constraints on the pyridopurinedione to dock the different ligands.

Biology. $\left[{ }^{3} \mathrm{H}\right] 8$-Ethyl-4-methyl-2-phenyl-(8R)-4,5,7,8-tetrahydro$1 \mathrm{H}$-imidazo[2,1-i]-purin-5-one ([$\left.{ }^{3} \mathrm{H}\right] \mathrm{PSB}-11$, specific activity $56 \mathrm{Ci}$ $\mathrm{mmol}^{-1}$ ) was a gift from Prof. C. E. Müller (University of Bonn, Germany). Unlabeled PSB-11, 1-deoxy-1-[6-[3- and 2-chloro-N6-(3iodobenzyl)-adenosine-5'- $\mathrm{N}$-methyluronamide]] (2-Cl-IB-MECA) were purchased from Tocris Ltd. (Abingdon, U.K.). 5'-N-Ethylcarboxamidoadenosine (NECA) was purchased from Sigma-Aldrich (Steinheim, Germany). Adenosine deaminase was purchased from Boehringer Mannheim (Mannheim, Germany). Bicinchoninic acid (BCA) and BCA protein assay reagents were purchased from Pierce Chemical Company (Rockford, IL). Chinese hamster ovary (CHO) cells stably expressing the human $\mathrm{A}_{3}$ adenosine receptor $\left(\mathrm{CHOhA}_{3}\right)$ were a gift from Dr. K.-N. Klotz (University of Würzburg, Germany). All other chemicals were obtained from standard commercial sources and were of analytical grade.

Cell Culture and Membrane Preparation. Chinese hamster ovary $(\mathrm{CHO})$ cells, stably expressing the human $\mathrm{A}_{3}$ adenosine receptor $\left(\mathrm{CHOhA}_{3}\right)$, were cultured and membranes were prepared and stored as previously reported. ${ }^{7,33}$ Protein determination was performed based on the bicinchoninic acid (BCA) method. ${ }^{34}$

Y265F 7.36 Site-Directed Mutagenesis. The single tyrosine mutation introduced in TM7 of the $\mathrm{hA}_{3} \mathrm{AR}$ was performed with the QuickChange II Site-Directed Mutagenesis system (Stratagene, Huizen, The Netherlands). The wild-type pcDNA3.1(+)-A AR plasmid DNA with $\mathrm{N}$-terminal $3 \times \mathrm{HA}$-tag was used as a template for polymerase chain reaction (PCR) mutagenesis. Mutant primers for directional PCR product cloning were designed using the online Quickchange primer design program (Agilent Technologies, Santa Clara, CA) and obtained from Eurogentec (Maastricht, The Netherlands). Forward primer used for this procedure was $5^{\prime}$ cacagcttgtgctgttcatgggcatcctgct- $3^{\prime}$ and the reverse primer was $5^{\prime}$ agcaggatgcccatgaacagcacaagctgtg- $3^{\prime}$. All DNA sequences were verified by Sanger sequencing at LGTC (Leiden, The Netherlands).

Transient Expression of Wild Type (WT) and Mutant Receptors in CHO-K1 Cells. CHO-K1 cells were seeded into 150 $\mathrm{mm}$ culture dishes to achieve $60 \%$ confluence in the presence of 20 $\mathrm{mL}$ culture medium consisting of Dulbecco's modified Eagle's medium/F12 (1:1) supplemented with $10 \%(\mathrm{v} / \mathrm{v})$ newborn calf serum, streptomycin $\left(50 \mu \mathrm{g} \mathrm{mL}^{-1}\right)$, and penicillin $\left(50 \mathrm{IU} \mathrm{mL}^{-1}\right)$. The cells were transfected approximately $24 \mathrm{~h}$ later with plasmid DNA (20 $\mu \mathrm{g}$ of DNA/dish) by the PEI method ${ }^{35}(\mathrm{PEI} / \mathrm{DNA}=3: 1)$ and left for $24 \mathrm{~h}$. Subsequently, the medium was removed and fresh medium containing $5 \mathrm{mM}$ sodium butyrate was added (to enhance the receptor expression level ${ }^{36}$ ), and cells were grown for an additional 24 $\mathrm{h}$ at $37{ }^{\circ} \mathrm{C}$ and $5 \% \mathrm{CO}_{2}$. Membrane preparation followed the procedure described above for the $\mathrm{CHO}$ cell membranes stably expressing the $\mathrm{hA}_{3} \mathrm{AR}^{7,33}$

Radioligand Displacement Assay. Radioligand displacement experiments were performed as in previously published methods. ${ }^{7}$ Membrane aliquots containing $15 \mu \mathrm{g}$ of protein were incubated in a total volume of $100 \mu \mathrm{L}$ assay buffer $\left(50 \mathrm{mM}\right.$ Tris- $\mathrm{HCl}, 5 \mathrm{mM} \mathrm{MgCl}_{2}$, supplemented with $0.01 \%$ 3-[(3-cholamidopropyl)dimethylammonio]-1-propanesulfonate and $1 \mathrm{mM}$ ethylenediaminetetraacetic acid (EDTA), pH 7.4) at $25^{\circ} \mathrm{C}$ for $120 \mathrm{~min}$. Displacement experiments were performed using six concentrations of competing antagonist in the presence of $\sim 10 \mathrm{nM}\left[{ }^{3} \mathrm{H}\right] \mathrm{PSB}-11$. Nonspecific binding was determined in the presence of $100 \mu \mathrm{m}$ NECA and represented less than $10 \%$ of total binding. Incubation was terminated by rapid filtration performed on 96-well GF/B filter plates (PerkinElmer, Groningen, the Netherlands) in a PerkinElmer Filtermate-harvester (PerkinElmer, Groningen, the Netherlands). After the filter plate was dried at $55{ }^{\circ} \mathrm{C}$ for $30 \mathrm{~min}$, the filter-bound radioactivity was determined by scintillation spectrometry using a 2450 MicroBeta $^{2}$ Plate Counter (PerkinElmer, Boston, MA).

Radioligand Competition Association Assay. The competition association assay was performed by incubation of $\sim 10 \mathrm{nM}$ $\left[{ }^{3} \mathrm{H}\right] \mathrm{PSB}-11$ in the absence or presence of the competing $\mathrm{hA}{ }_{3} \mathrm{AR}$ antagonist at its $\mathrm{IC}_{50}$ concentration with membrane aliquots. The amount of receptor-bound radioligand was determined at different time points up to $240 \mathrm{~min}$. Incubations were terminated and samples were obtained as described under the Radioligand Displacement Assay.

$\left[{ }^{35} \mathrm{~S}\right] \mathrm{GTP} \gamma \mathrm{S}$ Binding Assay. The assays were started by adding 15 $\mu \mathrm{g}$ of homogenized $\mathrm{CHOhA} 3$ membranes in an ice-cold assay buffer to a total volume of $80 \mu \mathrm{L}$ containing $50 \mathrm{mM}$ Tris $-\mathrm{HCl}$ buffer, $5 \mathrm{mM}$ $\mathrm{MgCl}_{2}, 1 \mathrm{mM}$ EDTA, $0.05 \%$ bovine serum albumin and $1 \mathrm{mM}$ dithiothreitol, $100 \mathrm{mM} \mathrm{NaCl}, \mathrm{pH}$ 7.4, supplemented with $1 \mu \mathrm{m}$ GDP and $5 \mu \mathrm{g}$ saponin. The assays were performed in a 96-well plate format, where stock solutions of the compounds were added to a total volume of $100 \mu \mathrm{L}$ using an HP D300 Digital Dispenser (Tecan, Männedorf, Switzerland). The final concentration of dimethyl sulfoxide (DMSO) per assay point was $\leq 0.1 \%$. The basal level of $\left[{ }^{35} \mathrm{~S}\right] \mathrm{GTP} \gamma \mathrm{S}$ binding was determined in the absence of the ligand, whereas the maximal level of $\left[{ }^{35} \mathrm{~S}\right] \mathrm{GTP} \gamma \mathrm{S}$ binding was determined in the presence of $10 \mu \mathrm{m}$ 2-Cl-IB-MECA. For the insurmountability experiments, membrane preparations were preincubated with or without antagonists $\left(0.1-, 1-, 3-, 10\right.$-fold $K_{\mathrm{i}}$ values $)$ for $60 \mathrm{~min}$ at $25^{\circ} \mathrm{C}$, prior to the addition of 2-Cl-IB-MECA $(10 \mu \mathrm{m}$ to $0.1 \mathrm{nM})$ and $20 \mu \mathrm{L}$ $\left.{ }^{35} \mathrm{~S}\right] \mathrm{GTP} \gamma \mathrm{S}$ (final concentration $\sim 0.3 \mathrm{nM}$ ), after which incubation continued for another $30 \mathrm{~min}$ at $25{ }^{\circ} \mathrm{C}$. For the surmountability (control) experiments, antagonists (1-, 3-, 10-fold $K_{\mathrm{i}}$ values) and 2-ClIB-MECA $(10 \mu \mathrm{m}$ to $0.1 \mathrm{nM})$ were co-incubated with $\left[{ }^{35} \mathrm{~S}\right] \mathrm{GTP} \gamma \mathrm{S}$ for $30 \mathrm{~min}$ at $25{ }^{\circ} \mathrm{C}$. For all experiments, incubations were terminated and samples were obtained as described under the Radioligand Displacement Assay, using GF/B filters (Whatman International, Maidstone, U.K.).

Data Analysis. All experimental data were analyzed using the nonlinear regression curve fitting program GraphPad Prism 7.0 (GraphPad Software, Inc., San Diego, CA). Data from the radioligand displacement assays were fit into one-site binding mode, and the obtained $\mathrm{IC}_{50}$ values were converted into $K_{\mathrm{i}}$ values using the ChengPrusoff equation to determine the affinity of the ligands. ${ }^{37}$ The observed association rate constants $\left(k_{\mathrm{obs}}\right)$ derived from both assays were obtained by fitting association data using one-phase exponential association. The dissociation rate constants were obtained by fitting dissociation data to a one phase exponential decay model. The $k_{\mathrm{obs}}$ values were converted into association rate constants $\left(k_{\text {on }}\right)$ using the equation $k_{\mathrm{on}}=\left(k_{\mathrm{obs}}-k_{\mathrm{off}}\right) /[\mathrm{L}]$, where $[\mathrm{L}]$ is the amount of radioligand used for the association experiments. Association and dissociation rate constants for unlabeled compounds were calculated by fitting the data into the competition association model using "kinetics of competitive binding". 22

$$
\begin{aligned}
K_{\mathrm{A}}= & k_{\mathrm{I}}[\mathrm{L}] \times 10^{-9}+k_{2} \\
K_{\mathrm{B}}= & k_{3}[\mathrm{I}] \times 10^{-9}+k_{4} \\
S= & \sqrt{\left(K_{\mathrm{A}}-K_{\mathrm{B}}\right)^{2}+4 \times k_{1} \times k_{3} \times L \times I \times 10^{-18}} \\
K_{\mathrm{F}}= & 0.5\left(K_{\mathrm{A}}+K_{\mathrm{B}}+S\right) \\
K_{\mathrm{S}}= & 0.5\left(K_{\mathrm{A}}+K_{\mathrm{B}}-S\right) \\
Q= & \frac{B_{\max } \times k_{1} \times L \times 10^{-9}}{K_{\mathrm{F}}-K_{\mathrm{S}}} \\
Y= & Q \times\left(\frac{k_{4} \times\left(K_{\mathrm{F}}-K_{\mathrm{S}}\right)}{K_{\mathrm{F}} \times K_{\mathrm{S}}}+\frac{k_{4}-K_{\mathrm{F}}}{K_{\mathrm{F}}} \mathrm{e}^{\left(-K_{\mathrm{F}} \times X\right)}\right. \\
& \left.-\frac{k_{4}-K_{S}}{K_{\mathrm{S}}} \mathrm{e}^{\left(-K_{\mathrm{S}} \times X\right)}\right)
\end{aligned}
$$

where $X$ is the time $(\min ), Y$ is the specific $\left[{ }^{3} \mathrm{H}\right]$ PSB- 11 binding (DPM), $k_{1}$ and $k_{2}$ are the $k_{\text {on }}\left(\mathrm{M}^{-1} \min ^{-1}\right)$ and $k_{\text {off }}\left(\min ^{-1}\right)$ of $\left[{ }^{3} \mathrm{H}\right]$ PSB-11, respectively, $B_{\max }$ is the total binding (DPM), $L$ is the radioligand concentration $(\mathrm{nM})$, and $I$ is the concentration of the unlabeled competitor $(\mathrm{nM})$. Association and dissociation rate constants for $\left[{ }^{3} \mathrm{H}\right]$ PSB-11 $\left(k_{1}=0.281 \pm 0.04 \times 10^{8} \mathrm{M}^{-1} \mathrm{~min}^{-1}\right.$ and $k_{2}=0.3992 \pm 0.02 \mathrm{~min}^{-1}$ ) were obtained from Xia et al. ${ }^{7}$ With 
that, the $k_{3}, k_{4}$, and $B_{\max }$ were calculated, where $k_{3}$ represents the $\mathrm{k}_{\text {on }}$ $\left(\mathrm{M}^{-1} \mathrm{~min}^{-1}\right)$ of the unlabeled ligand, $k_{4}$ stands for the $k_{\text {off }}\left(\mathrm{min}^{-1}\right)$ of the unlabeled ligand and $B_{\max }$ equals the total binding (DPM). All competition association data were globally fitted. The residence time (RT, in $\min$ ) was calculated using the equation $\mathrm{RT}=1 / k_{\text {off }}$, as $k_{\text {off }}$ values are expressed in $\min ^{-1}$. $\left[{ }^{35} S\right]$ GTP $\gamma S$ binding curves were analyzed by nonlinear regression using "log (agonist) vs responsevariable slope" to obtain potency, inhibitory potency, or efficacy values of agonists and antagonists $\left(\mathrm{EC}_{50}\right.$ and $E_{\max }$ respectively). In the (in)surmountability assays, Schild $\mathrm{EC}_{50}$ shift equations were used to obtain Schild-slopes and $\mathrm{p} A_{2}$ values. All experimental values obtained are means of three independent experiments performed in duplicate.

\section{ASSOCIATED CONTENT}

\section{S Supporting Information}

The Supporting Information is available free of charge on the ACS Publications website at DOI: 10.1021/acs.jmedchem.8b02026.

Overlay of a crystal structure of compound 2 bound to human adenosine $A_{1}$ receptor (PDB: 5UEN) and a $\mathrm{hA}_{3} \mathrm{AR}$ homology model with $\mathbf{1 7} \mathbf{b}$ docked (PDF)

Homology model of $\mathrm{hA}_{3} \mathrm{AR}$ with $\mathbf{1 7 b}$ (PDB)

Molecular formula strings with bioactivity (CSV)

\section{AUTHOR INFORMATION}

\section{Corresponding Author}

*E-mail: ijzerman@lacdr.leidenuniv.nl. Tel: +31-71-527-4651. ORCID $\odot$

Daan van der Es: 0000-0003-3662-8177

Adriaan P. IJzerman: 0000-0002-1182-2259

\section{Author Contributions}

X.Y., L.H.H., and A.P.I. conceived the study. L.H.H., D.v.d.E., and A.P.I. supervised the project. Chemical synthesis was designed and supervised by X.Y. and J.P.D.v.V. and performed by J.O., B.J.K., and J.P.D.v.V. The bioassays were supervised by L.H.H and performed by X.Y. The computational work was performed by E.B.L. The manuscript was written by X.Y., L.H.H., D.v.d.E., and A.P.I.

\section{Notes}

The authors declare no competing financial interest.

The homology model was based on the crystal structure of the adenosine $\mathrm{A}_{2 \mathrm{~A}}$ receptor (PDB: 4EIY). Authors will release the atomic coordinates upon article publication.

\section{ACKNOWLEDGMENTS}

We thank Prof C. E. Müller (Bonn University, Germany) for her kind help in obtaining $\left[{ }^{3} \mathrm{H}\right] \mathrm{PSB}-11$, the radiolabeled probe used in this study. We are also thankful to our colleague, Lindsey Burggraaff, for her assistance with computational modeling studies and Ing. G.K. Spijksma for assistance with HRMS. X.Y. is supported by a grant from the Chinese Scholarship Council.

\section{ABBREVIATIONS}

$\mathrm{BCA}$, bicinchoninic acid; $\mathrm{CHO}$, Chinese hamster ovary; $\mathrm{CHO}$ $\mathrm{K} 1$, a subclone from the parental $\mathrm{CHO}$ cell line; 2-Cl-IBMECA, 1-[2-chloro-6-[[(3-iodophenyl)methyl $]$ amino $]-9 H$ purin-9-yl]-1-deoxy- $N$-methyl- $\beta$-D-ribofuranuronamide; DBU, 1,8-diazabicyclo[5.4.0] undec-7-ene; EDC, 1-ethyl-3-(3dimethylaminopropyl)carbodiimide; $E_{\max }$ maximum response elicited by an unlabeled ligand in a functional assay (relatively to 2-Cl-IB-MECA) at membranes of $\mathrm{CHO}$ cells stably expressing the $\mathrm{A}_{3}$ adenosine receptor; EtOAc, ethyl acetate; G418, geneticin; GTP $\gamma$, guanosine 5' $-O-[\gamma$-thio $]$ triphosphate; $h A_{1} A R$, human $A_{1}$ adenosine receptor; $h A_{3} A R$, human $A_{3}$ adenosine receptor; $\mathrm{MeCN}$, acetonitrile; NECA, 5'-(Nethylcarboxamide)adenosine; PSB-11, 8-Ethyl-4-methyl-2-phenyl-(8R)-4,5,7,8-tetrahydro-1H- imidazo[2,1-i]-purin-5-one

\section{REFERENCES}

(1) Fredholm, B. B.; IJzerman, A. P.; Jacobson, K. A.; Klotz, K. N.; Linden, J. International Union of Pharmacology. XXV. Nomenclature and classification of adenosine receptors. Pharmacol. Rev. 2001, 53, 527-552.

(2) Ali, H.; Cunhamelo, J. R.; Saul, W. F.; Beaven, M. A. Activation of phospholipase-C via adenosine receptors provides synergistic signals for secretion in antigen-stimulated $\mathrm{Rbl}-2 \mathrm{~h} 3$ cells - evidence for a novel adenosine receptor. J. Biol. Chem. 1990, 265, 745-753.

(3) Borea, P. A.; Varani, K.; Vincenzi, F.; Baraldi, P. G.; Tabrizi, M. A.; Merighi, S.; Gessi, S. The $A_{3}$ adenosine receptor: history and perspectives. Pharmacol. Rev. 2015, 67, 74-102.

(4) Yang, H.; Avila, M. Y.; Peterson-Yantorno, K.; Coca-Prados, M.; Stone, R. A.; Jacobson, K. A.; Civan, M. M. The cross-species $A_{3}$ adenosine-receptor antagonist MRS 1292 inhibits adenosine-triggered human nonpigmented ciliary epithelial cell fluid release and reduces mouse intraocular pressure. Curr. Eye Res. 2005, 30, 747-754.

(5) Brown, R. A.; Spina, D.; Page, C. P. Adenosine receptors and asthma. Br. J. Pharmacol. 2008, 153, S446-456.

(6) Priego, E. M.; Perez-Perez, M. J.; von Frijtag Drabbe Kuenzel, J. K.; de Vries, H.; IJzerman, A. P.; Camarasa, M. J.; Martin-Santamaria, S. Selective human adenosine $A_{3}$ antagonists based on pyrido[2,1$f$ ]purine-2,4-diones: novel features of $\mathrm{hA}_{3}$ antagonist binding. ChemMedChem 2008, 3, 111-119.

(7) Xia, L.; Burger, W. A. C.; van Veldhoven, J. P. D.; Kuiper, B. J.; van Duijl, T. T.; Lenselink, E. B.; Paasman, E.; Heitman, L. H.; IJzerman, A. P. Structure-affinity relationships and structure-kinetics relationships of pyrido[2,1-f]purine-2,4-dione derivatives as human adenosine $\mathrm{A}_{3}$ receptor antagonists. J. Med. Chem. 2017, 60, 75557568.

(8) Priego, E. M.; Kuenzel, J. V.; IJzerman, A. P.; Camarasa, M. J.; Perez-Perez, M. J. Pyrido[2,1-f]purine-2,4-dione derivatives as a novel class of highly potent human $\mathrm{A}_{3}$ adenosine receptor antagonists. $J$. Med. Chem. 2002, 45, 3337-3344.

(9) Weichert, D.; Gmeiner, P. Covalent molecular probes for class A $\mathrm{G}$ protein-coupled receptors: advances and applications. ACS Chem. Biol. 2015, 10, 1376-1386.

(10) Murrison, E. M.; Goodson, S. J.; Edbrooke, M. R.; Harris, C. A. Cloning and characterisation of the human adenosine $A_{3}$ receptor gene. FEBS Lett. 1996, 384, 243-246.

(11) Glukhova, A.; Thal, D. M.; Nguyen, A. T.; Vecchio, E. A.; Jorg, M.; Scammells, P. J.; May, L. T.; Sexton, P. M.; Christopoulos, A. Structure of the adenosine $A_{1}$ receptor reveals the basis for subtype selectivity. Cell 2017, 168, 867-877.

(12) Li, A. H.; Chang, L.; Ji, X. D.; Melman, N.; Jacobson, K. A. Functionalized congeners of 1,4-dihydropyridines as antagonist molecular probes for $\mathrm{A}_{3}$ adenosine receptors. Bioconjugate Chem. 1999, 10, 667-677.

(13) Baraldi, P. G.; Cacciari, B.; Moro, S.; Romagnoli, R.; Ji, X. D.; Jacobson, K. A.; Gessi, S.; Borea, P. A.; Spalluto, G. Fluorosulfonyland bis-(beta-chloroethyl)amino-phenylamino functionalized pyrazolo[4,3-e]1,2,4-triazolo[1,5-c]pyrimidine derivatives: irreversible antagonists at the human $\mathrm{A}_{3}$ adenosine receptor and molecular modeling studies. J. Med. Chem. 2001, 44, 2735-2742.

(14) Ji, X. D.; Gallorodriguez, C.; Jacobson, K. A. A selective agonist affinity label for $\mathrm{A}_{3}$ adenosine receptors. Biochem. Biophys. Res. Commun. 1994, 203, 570-576.

(15) Yang, X.; Michiels, T. J. M.; de Jong, C.; Soethoudt, M.; Dekker, N.; Gordon, E.; van der Stelt, M.; Heitman, L. H.; van der Es, D.; IJzerman, A. P. An affinity-based probe for the human adenosine $\mathrm{A}_{2 \mathrm{~A}}$ receptor. J. Med. Chem. 2018, 61, 7892-7901. 
(16) Picone, R. P.; Fournier, D. J.; Makriyannis, A. Ligand based structural studies of the $\mathrm{CB}_{1}$ cannabinoid receptor. J. Pept. Res. 2002, $60,348-356$.

(17) Narayanan, A.; Jones, L. H. Sulfonyl fluorides as privileged warheads in chemical biology. Chem. Sci. 2015, 6, 2650-2659.

(18) Grimster, N. P.; Connelly, S.; Baranczak, A.; Dong, J. J.; Krasnova, L. B.; Sharpless, K. B.; Powers, E. T.; Wilson, I. A.; Kelly, J. W. Aromatic sulfonyl fluorides covalently kinetically stabilize transthyretin to prevent amyloidogenesis while affording a fluorescent conjugate. J. Am. Chem. Soc. 2013, 135, 5656-5668.

(19) Müller, C. E.; Diekmann, M.; Thorand, M.; Ozola, V. $\left[{ }^{3} \mathrm{H}\right] 8$ Ethyl-4-methyl-2-phenyl-(8R)-4,5,7,8-tetrahydro-1H-imidazo[2,1-f]purin-5-one $\left(\left[{ }^{3} \mathrm{H}\right] \mathrm{PSB}-11\right)$, a novel high-affinity antagonist radioligand for human $\mathrm{A}_{3}$ adenosine receptors. Bioorg. Med. Chem. Lett. 2002, 12, 501-503.

(20) Weichert, D.; Kruse, A. C.; Manglik, A.; Hiller, C.; Zhang, C.; Hubner, H.; Kobilka, B. K.; Gmeiner, P. Covalent agonists for studying G protein-coupled receptor activation. Proc. Natl. Acad. Sci. U.S.A. 2014, 111, 10744-10748.

(21) Yang, X.; Dong, G.; Michiels, T. J. M.; Lenselink, E. B.; Heitman, L.; Louvel, J.; IJzerman, A. P. A covalent antagonist for the human adenosine $A_{2 A}$ receptor. Purinergic Signalling 2017, 13, 191201.

(22) Motulsky, H. J.; Mahan, L. C. The kinetics of competitive radioligand binding predicted by the law of mass-action. Mol. Pharmacol. 1984, 25, 1-9.

(23) Doornbos, M. L. J.; Wang, X.; Vermond, S. C.; Peeters, L.; Perez-Benito, L.; Trabanco, A. A.; Lavreysen, H.; Cid, J. M.; Heitman, L. H.; Tresadern, G.; IJzerman, A. P. Covalent allosteric probe for the metabotropic glutamate receptor 2: design, synthesis, and pharmacological characterization. J. Med. Chem. 2018, 223-233.

(24) Jörg, M.; Glukhova, A.; Abdul-Ridha, A.; Vecchio, E. A.; Nguyen, A. T. N.; Sexton, P. M.; White, P. J.; May, L. T.; Christopoulos, A.; Scammells, P. J. Novel irreversible agonists acting at the $\mathrm{A}_{1}$ adenosine receptor. J. Med. Chem. 2016, 59, 11182-11194.

(25) van Muijlwijk-Koezen, J. E.; Timmerman, H.; van der Sluis, R. P.; van de Stolpe, A. C.; Menge, W. M. P. B.; Beukers, M. W.; van der Graaf, P. H.; de Groote, M.; IJzerman, A. P. Synthesis and use of FSCPX, an irreversible adenosine $\mathrm{A}_{1}$ antagonist, as a 'receptor knockdown' tool. Bioorg. Med. Chem. Lett. 2001, 11, 815-818.

(26) Strange, P. G. Use of the GTP gamma S ([ ${ }^{35}$ S $]$ GTP gamma $S$ and Eu-GTP gamma $S$ ) binding assay for analysis of ligand potency and efficacy at $\mathrm{G}$ protein-coupled receptors. Br. J. Pharmacol. 2010, $161,1238-1249$.

(27) Liu, W.; Chun, E.; Thompson, A. A.; Chubukov, P.; Xu, F.; Katritch, V.; Han, G. W.; Roth, C. B.; Heitman, L. H.; IJzerman, A. P.; Cherezov, V.; Stevens, R. C. Structural basis for allosteric regulation of GPCRs by sodium ions. Science 2012, 337, 232-236.

(28) Picone, R. P.; Khanolkar, A. D.; Xu, W.; Ayotte, L. A.; Thakur, G. A.; Hurst, D. P.; Abood, M. E.; Reggio, P. H.; Fournier, D. J.; Makriyannis, A. (-)-7'-Isothiocyanato-11-hydroxy-1 ',1'-dimethylheptylhexahydrocannabinol (AM841), a high-affinity electrophilic ligand, interacts covalently with a cysteine in helix six and activates the CB1 cannabinoid receptor. Mol. Pharmacol. 2005, 68, 1623-1635.

(29) Singh, J.; Petter, R. C.; Baillie, T. A.; Whitty, A. The resurgence of covalent drugs. Nat. Rev. Drug Discovery 2011, 10, 307-317.

(30) Soethoudt, M.; Stolze, S. C.; Westphal, M. V.; van Stralen, L.; Martella, A.; van Rooden, E. J.; Guba, W.; Varga, Z. V.; Deng, H.; van Kasteren, S. I.; Grether, U.; IJzerman, A. P.; Pacher, P.; Carreira, E. M.; Overkleeft, H. S.; Ioan-Facsinay, A.; Heitman, L. H.; van der Stelt, M. Selective photoaffinity probe that enables assessment of cannabinoid $\mathrm{CB}_{2}$ receptor expression and ligand engagement in human cells. J. Am. Chem. Soc. 2018, 140, 6067-6075.

(31) Goebel, U.; Siepe, M.; Schwer, C.; Schlensak, C.; Loop, T. Sevoflurane-induced preconditioning in the isolated mouse heart is mediated by $\mathrm{A}_{1}$-and $\mathrm{A}_{3}$-adenosine receptors. Eur. J. Anaesthesiol. 2010, 27,72 .
(32) Sherman, W.; Day, T.; Jacobson, M. P.; Friesner, R. A.; Farid, R. Novel procedure for modeling ligand/receptor induced fit effects. J. Med. Chem. 2006, 49, 534-553.

(33) Heitman, L. H.; Göblyös, A.; Zweemer, A. M.; Bakker, R.; Mulder-Krieger, T.; van Veldhoven, J. P. D.; de Vries, H.; Brussee, J.; IJzerman, A. P. A series of 2,4-disubstituted quinolines as a new class of allosteric enhancers of the adenosine $\mathrm{A}_{3}$ receptor. J. Med. Chem. 2009, 52, 926-931.

(34) Smith, P. K.; Krohn, R. I.; Hermanson, G. T.; Mallia, A. K.; Gartner, F. H.; Provenzano, M. D.; Fujimoto, E. K.; Goeke, N. M.; Olson, B. J.; Klenk, D. C. Measurement of protein using bicinchoninic acid. Anal. Biochem. 1985, 150, 76-85.

(35) Boussif, O.; Lezoualch, F.; Zanta, M. A.; Mergny, M. D.; Scherman, D.; Demeneix, B.; Behr, J. P. A versatile vector for gene and oligonucleotide transfer into cells in culture and in-vivo polyethylenimine. Proc. Natl. Acad. Sci. U.S.A. 1995, 92, 7297-7301.

(36) Gorman, C. M.; Howard, B. H.; Reeves, R. Expression of recombinant plasmids in mammalian-cells is enhanced by sodiumbutyrate. Nucleic Acids Res. 1983, 11, 7631-7648.

(37) Yung-Chi, C.; Prusoff, W. H. Relationship between the inhibition constant $\left(K_{\mathrm{I}}\right)$ and the concentration of inhibitor which causes 50 per cent inhibition $\left(I_{50}\right)$ of an enzymatic reaction. Biochem. Pharmacol. 1973, 22, 3099-3108. 